\title{
¿Es necesaria una reforma de los derechos de la víctima en el proceso penal español?
}

\author{
Juan-Luis Gómez Colomer*
}

\section{Resumen}

El texto se ocupa del papel reservado a la víctima del delito en el proceso penal español, los derechos que le asisten dentro y fuera del mismo y a su alcance, con ocasión de la reforma que se promueve en la legislación ibérica sobre la materia. La modificación del ordenamiento referido se aborda con una visión crítica, la cual le permite al autor concluir que, más allá de las reformas legislativas, debe propenderse por el cambio en algunas prácticas de los poderes públicos frente al tratamiento de las víctimas, especialmente en tratándose de las más vulnerables.

\section{Palabras clave}

Proceso penal español, víctima del delito, reforma, papel de la víctima en el proceso penal, derechos procesales, derechos no procesales.

\footnotetext{
Artículo resultado de la Conferencia impartida por el autor en la inauguración de la VII Cohorte de la Maestría en Derecho, Línea de Derecho Procesal Penal, codirigida por él y el Profesor Fernando Velásquez, en la Universidad Sergio Arboleda, Bogotá (Colombia), los días 27 y 28 de febrero de 2014.

* Dr. Dr. h.c., Catedrático de Derecho Procesal, Universidad Jaume I de Castellón (España); Codirector y Profesor de la Maestría en Derecho, Programa de Derecho Procesal, Penal; Profesor de la Especialización en Derecho Penal de la Universidad Sergio Arboleda.
} 


\title{
Is a Reform of the Rights of the Victim in the Spanish Criminal Proceedings Necessary?
}

\begin{abstract}
The text deals with the role reserved to the crime victim in the Spanish criminal proceedings, his/her rights inside and outside the same and within his / her reach, on the occasion of the reform promoted in the Iberian legislation on the subject. The modification of that order is aproached with a critical view, which allows the author to conclude that, beyond legislative reforms, there must be a move towards the change in some practices of public authorities against the treatment of victims, especially in the case of the most vulnerable ones.
\end{abstract}

\section{Keywords}

Spanish criminal proceedings, victims of crime, reform, role of the victim in criminal proceedings, procedural rights, not procedural rights. 


\section{Introducción: el futuro Estatuto Jurídico de la Víctima del Delito}

La visión española de la víctima del delito en el proceso penal puede abordarse desde diversas perspectivas, pero destaca ante todo la de su situación jurídico-procesal actual, que es paradójicamente 'ideal' si se le compara con la existente en los países que mayor influencia jurídica tienen en España, como son Alemania, Italia, Estados Unidos y en la inmensa mayoría de los demás (Gómez, 2014).

Pero eso no quiere decir que no se planteen muchos problemas en determinados aspectos. Es particularmente remarcable, para poner el ejemplo más importante, la lucha de la víctima por el reconocimiento de sus derechos en determinados delitos en los que como persona resulta muy vulnerable (acoso sexual, agresión sexual, violación, acoso laboral, trato degradante, menoscabo grave de la integridad, actos hostiles y humillantes, vejaciones y maltrato psicológico, y violencia de género), lo que afecta especialmente desde el punto de vista procesal a la investigación y prueba de los mismos.

España no ha cambiado todavía su sistema de enjuiciamiento criminal, basado en el proceso penal francés acusatorio formal o mixto, al sistema adversarial de origen anglosajón, principalmente al que se considera hoy modelo, el proceso penal federal de los Estados Unidos de América. Lo ha intentado, pero en el momento de escribir estas páginas todavía no lo ha logrado.

La verdad es que si atendiéramos exclusivamente a la situación jurídico-procesal penal de la víctima del delito, la regulación actual no debería ser modificada profundamente (naturalmente, siempre habría cosas que mejorar), o al menos no tan drásticamente como un cambio de sistema supondría. Más bien, deberían modificarse algunas actitudes prácticas de los poderes públicos en la investigación de ciertos delitos con víctimas vulnerables, reconsiderar el valor probatorio de la declaración de la víctima cuando es testigo, y brindar una mayor efectividad de las medidas de protección cuando la víctima está realmente en peligro. Con ello sería prácticamente suficiente.

La pregunta inicial que deberíamos hacernos, antes de entrar en este tipo de cuestiones, es ¿qué papel tiene reservada la víctima del delito en nuestro proceso penal? o ¿qué papel debería tener reservado?, por mejor decir deberíamos empezar por preguntarnos ¿qué interés tiene la víctima en participar en el proceso penal?, ¿qué quiere realmente? 
Estas preguntas pueden contestarse desde dos puntos de vista. Una primera respuesta, más bien propia del romanticismo jurídico liberal, diría que la víctima es parte de la sociedad, pero que al ser la parte más dañada por la comisión del delito tiene como miembro de dicha sociedad un derecho legítimo y prioritario a que la paz social quede restablecida cuanto antes, por lo que su interés primordial es controlar el juicio contra el autor del delito, participando en él de la manera más amplia posible. Quiere, por tanto, que se le restituya en la dignidad que el autor del delito ha puesto en tela de juicio y, de paso, que la sociedad vuelva a la tranquilidad y paz amenazadas por ese hecho.

Pero una segunda respuesta, mucho más cercana a la realidad, aunque no niega el romanticismo, lo aparca hasta casi oscurecerlo, porque deduce de la práctica que el único interés de la víctima es, en verdad, que se dejen las cosas como estaban antes de la comisión del delito, es decir, quiere sólo que se le repare en lo material o económico, y a ser posible también en lo ideal o moral.

En nuestra opinión, el tema es más complejo, porque si se observa esa misma realidad, la víctima quiere alguna, algunas o todas estas cosas: la asistencia personal inmediata tras la comisión del delito; que se le informe jurídicamente de sus derechos en manera comprensible; que se le garantice protección frente al delincuente en todo momento; la restitución de la cosa robada, hurtada o dañada; la reparación del daño material sufrido; la indemnización de los daños morales ocasionados; la detención del autor de delito, su enjuiciamiento y condena; el reconocimiento de los hechos por parte del autor del delito; que se le pida perdón; y, en su caso, el cumplimiento de lo acordado.

A ser posible lo querría todo, por eso la clave está en decidir qué nivel de influencia puede tener la respuesta a estas preguntas en el desarrollo del proceso penal. La mejor vía para analizar esa concreción es observando los derechos de la víctima del delito en el proceso penal, tanto si decide ser parte como si no, deduciendo de su conducta lo que realmente quiere. He de aclarar previamente que no me ocuparé de los derechos actuales de la víctima del delito, tanto sus derechos fundamentales, contemplando en ellos los procesales y los no procesales, como sus derechos ordinarios, con igual subdivisión también, porque hemos tenido ocasión de tratar el tema ampliamente en un reciente libro (Gómez, 2014, pp. 234 y ss.). 
La legislación española en materia de víctimas del delito va a ser reformada por imperativo legal. Ese imperativo es la obligada adaptación a España de la Directiva 29 del 25 de octubre de 2012 del Parlamento Europeo y del Consejo "Por la que se establecen normas mínimas sobre los derechos, el apoyo y la protección de las víctimas de delitos (2012/29/UE), y por la que se sustituye la Decisión marco 2001/220/AI del Consejo" (De Hoyos, 2014), que va a ser transpuesta mediante una ley ordinaria, llamada Ley del Estatuto Jurídico de la Víctima del Delito (abreviado, PLEVict), que en el momento de escribir estas líneas ha iniciado su tramitación parlamentaria en el Senado ${ }^{1}$. La propuesta contiene una exposición de motivos, 35 artículos, una disposición adicional, una disposición transitoria, una disposición derogatoria general y siete disposiciones finales. Está previsto que entre en vigor a los seis meses de su publicación oficial en el BOE.

Es importante llamar la atención ya en estos momentos sobre el hecho de que el texto español va mucho más allá de la trasposición de la Directiva citada, que se contiene en varios preceptos del PLEVict y en las modificaciones que en el mismo se ordenan de la Ley de Enjuiciamiento Criminal y del Código Penal (mediante sus disposiciones finales segunda y tercera básicamente), porque se pretende dar una respuesta lo más amplia posible a las víctimas, excediendo del ámbito estrictamente jurídico al social.

El PLEVict recoge un catálogo general de derechos comunes a todas las víctimas que se va desarrollando, posteriormente, a lo largo del articulado y se refiere tanto a los servicios de apoyo como a los de justicia reparadora que se establezcan legalmente, y a las actuaciones a lo largo del proceso penal en todas sus fases-incluidas las primeras diligencias y la ejecución-, con independencia del resultado del proceso penal. En ese catálogo general se contemplan, entre otros, los derechos a la información, a la protección y al apoyo en todo caso, a participar activamente en el proceso penal, al reconocimiento como tal de víctima y a un trato respetuoso,

${ }^{1}$ El correspondiente anteproyecto de ley fue presentado al Consejo de Ministros el día 1 de agosto de 2014 para su aprobación, teniendo en cuenta el Informe del Consejo de Estado (y los demás antecedentes), lo que así sucedió, convirtiéndose en proyecto de ley ordinaria, remitido el día 2 de agosto a las Cortes y publicado oficialmente, una vez calificado, en el Diario de Sesiones del Congreso de los Diputados con fecha 5 de septiembre de 2014 (Proyecto de ley 115-1 de 2014). 
profesional, individualizado y no discriminatorio (Exposición de Motivos, apartado IV, PLEVict).

Obviamente, se requiere un desarrollo de los derechos de las víctimas, porque son muchos y algunos de difícil clasificación. Lo abordamos a continuación, pero fijándonos estrictamente en los derechos procesales de la víctima, sea o no parte en el proceso, por ser en este aspecto en donde está el núcleo principal de la futura ley.

En general, el art. 3 PLEVict, que traspone el art. 1.1 de la Directiva 29 de 2012, establece y desarrolla con detalle una serie de derechos de las víctimas que podríamos llamar derechos ordinarios. Los derechos que se recogen son claros, aunque formulados con carácter excesivamente general algunos, como el derecho a participar en el proceso penal. Por eso se concretan en el articulado más adelante. Requieren, además, desarrollo reglamentario, lo cual, en lo que a lo procesal en particular se refiere, puede ser inconstitucional si afecta a su contenido esencial.

Tal listado es claramente imperfecto y, además, es incompleto o al menos no es del todo claro en qué consiste algún derecho o cómo debe aplicarse. Es incompleto porque debería haberse mencionado expresamente el derecho más importante para la víctima, el de su indemnización, que puede lograrse o no a través de la justicia restaurativa, sí mencionada, y, por ello, debería haberse incluido expresamente, conforme lo propuso el Consejo de Estado en su "Dictamen sobre el anteproyecto de ley orgánica del estatuto de la víctima del delito" (2014, p. 16).

En cualquier caso, los derechos recogidos en este precepto necesitan en su mayor parte de complementación con lo dispuesto en normas internacionales sobre determinadas víctimas vulnerables que la norma ni deroga ni puede derogar (Gómez, 2014, pp. 227 y ss.). El propio texto regula detalladamente en el Título I lo que llama 'derechos básicos' (arts. 4 a 10), que cobijan a la víctima tanto si es parte en el proceso penal como si queda fuera del mismo, mientras que en el Título II, bajo la denominación ‘Participación de la víctima en el proceso penal' regula, entre otros temas, una serie de derechos estrictamente procesales (arts. 11 a 18).

Por ello, resulta más fácil de analizar una clasificación de los derechos básicos de la víctima si distinguimos entre los no procesales y 
los procesales. Al menos sabremos dónde ubicar cada uno de ellos. Es más, dentro de los procesales deberíamos distinguir entre derechos procesales penales y derechos procesales no penales.

Los derechos extraprocesales o básicos de la víctima tienen legalmente una justificación, como consta en el apartado $\mathrm{V}$ de la exposición de motivos del PLEVict, cual es, esencialmente, que esta pueda obtener información sobre qué hacer y protección y asistencia inicial e inmediata frente a los daños causados. Mientras que los derechos procesales o a causa de su participación en el proceso penal, se explican legalmente en el apartado VI de la exposición de motivos del PLEVict, por la necesidad de reforzar los derechos actualmente existentes o en implementar nuevos derechos, especialmente en aquellas fases del proceso, como en la ejecución de la pena, en los que hasta ahora no tenía ninguno.

\section{Derechos no procesales}

Se regulan dos: el derecho de la víctima de una catástrofe, calamidad o suceso con gran número de víctimas a que no se le perturbe mientras decide qué hacer una vez ha sufrido el delito y el derecho de la víctima a acceder a los servicios de asistencia y apoyo.

\section{Derecho a no ser molestada por abogados y procuradores en búsqueda fácil de clientes cuando sea víctima de una catástrofe, calamidad pública o sucesos con elevado número de víctimas que puedan constituir delito.}

El PLEVict recoge en su art. 8 este derecho -una verdadera novedad del Proyecto de Ley Orgánica, sin referente alguno- que regula el período de reflexión en garantía de los derechos de la víctima. De película norteamericana, pero made in Spain, porque esta norma no está en la Directiva 2012/29/UE y, por lo tanto, es cosecha propia. El eufemismo del título legal del precepto lo dice todo. Se quiere acabar con la mala imagen profesional de que el abogado venda sus servicios en el lecho de muerte de las víctimas en los hospitales. Pero sólo durante un mes. Y si es la víctima la que los ha solicitado, la prohibición no existe.

En definitiva, se trata de garantizar el derecho de la víctima a escoger libremente a su abogado y procurador, sin agobios ni presiones mediáticas producidas por la catástrofe o calamidad sufrida, que sin duda habrá afectado a su estado de ánimo. El 
problema es que una disposición semejante ya existe en nuestro ordenamiento jurídico, pues tanto el Estatuto General de la Abogacía de 2001 (art. 25.2, c) como el Código Deontológico de la Abogacía Española de 2002 (art. 7.2, e) la prevén específicamente; esta es la razón por la cual el "Informe del Consejo General de la abogacia", citado en el "Dictamen sobre el anteproyecto de ley orgánica del estatuto de la víctima del delito", emitido por el Consejo de Estado (2014, p. 8), pide su supresión, sin que tal solicitud hubiera sido atendida. Por lo dicho, no es este el lugar de su regulación y debería salir del PLEVict en su tramitación parlamentaria.

\section{Derecho de acceso a los servicios de asistencia y apoyo.}

Este segundo derecho no solamente se concreta en la regulación del mismo, sino que establece, además, las normas básicas por las que se regularán los Servicios de Asistencia y Apoyo y los profesionales que formarán parte de ellos.

\section{El derecho de acceder se regula en el art. 10 PLEVict.}

Resulta fácilmente comprensible que articular un derecho de acceso de la víctima a la Justicia puede quedar en meras palabras idealizadas si no se ponen los medios para que dicho acceso sea efectivo. En el caso de las víctimas, como respecto a los ciudadanos en general, dado que no todos tienen las mismas posibilidades (ni la misma inteligencia o facilidad de comprensión), la canalización de este derecho tiene lugar fuera de instancias procesales, bien en el seno de un organismo público creado ad hoc, bien en una oficina de asistencia a las víctimas de naturaleza privada.

Para que sea realmente efectivo, la ley garantiza que el acceso sea gratuito y confidencial. Que no se especifique qué familiares de la víctima tienen este derecho puede crear problemas aquí, pues no sabemos para quiénes será gratuito y para quiénes no (Consejo General del Poder Judicial, 2014, p. 26 y Consejo de Estado, 2014, p. 18). Dada la prohibición de que la aplicación de esta ley cause más gasto público (Disposición Final $6^{\mathrm{a}}$ ), se tendrá que organizar con los medios ahora existentes, lo cual, a la vista de la situación económica actual, puede significar sencillamente que el derecho de acceso quede francamente impedido.

Como su desarrollo se tiene que hacer reglamentariamente, esperemos a comprobar la imaginación del legislador para evitarlo. 
Creemos que se echará mano de los servicios ya existentes, como los de atención a las víctimas de la violencia de género, lo que creará más problemas de los que solucionará, por ejemplo, su colapso o mitigación de la atención particularizada y priorizada a las mismas. La gran ventaja de esta organización específica es que la víctima puede recibir, además de información jurídica, un apoyo individualizado que le ayude a resolver, si los tiene y es el caso, sus problemas psicológicos, sociales y económicos derivados del hecho delictivo que ha sufrido. Es un paliativo, que debería ser muy eficaz, de la victimización primaria en la que se encuentra ya incursa desde la comisión del delito, porque se trata de desvictimizarla cuanto antes.

Lo que hace, por ende, el PLEVict es acoger en España el concepto de victimo-asistencia en forma organizada y con carácter general, al igual que tantos países que manifiestan una verdadera preocupación por la protección de las víctimas, y no sólo respecto a ciertas víctimas como ocurría hasta ahora, fundamentalmente, las de delitos dolosos violentos y contra la libertad sexual (art. 16 de la Ley 35 de1995), o con base en iniciativas demasiado tímidas y sectorializadas ${ }^{2}$. Se funda en el concepto de asistencia integral aplicado a la víctima, surgido en la ONU en el año de $1985^{3}$. Para Europa es clave la Recomendación 8 de 2006, de 14 de junio", "Sobre asistencia a las víctimas de delitos", además de la Directiva 29 del 25 de octubre

\footnotetext{
${ }^{2}$ Desde finales del siglo pasado se pusieron en marcha oficinas de asistencia a las víctimas de delito, de naturaleza pública, en determinados juzgados. Oficialmente todo empieza a moverse a partir de 1995, pero antes hubo iniciativas amparada por el Consejo General del Poder Judicial, la Fiscalía General del Estado y el Ministerio de Justicia o la respectiva Comunidad Autónoma: Valencia capital en 1985 fue la pionera. Más información en http: / / www.mjusticia.gob.es / BUSCADIR/ServletControlador?apartado= buscadorPorProvincias\&ente $=4625093350000 \& l a n g=e s \_$es\&origen $=\&$ tipo $=$ ATV\&provincia $=46$. Con todo, su éxito ha sido muy relativo. Para mayor información, en lo que afecta al Estado, consultar en http: / / www.mjusticia. gob.es/cs/Satellite/es / 1288774766880 / EstructuraOrganica.html.

${ }_{3}^{3}$ Vide, la Declaración de las Naciones Unidas de 29 de noviembre de 1985, sobre los principios básicos de justicia para las víctimas del crimen y de abuso de poder, Resolución 40/34. Recuperado de http:/ / funvic.org/ paginas/legislacion/legi2.htm. Se ha editado también un "Manual de justicia sobre el uso y aplicación de la declaración de principios básicos de justicia para víctimas del delito y abuso de poder". Recuperado de http: / / www.pgjdf.gob.mx/temas/4-6-1 / fuentes/12-A-4.pdf.

${ }^{4}$ El texto oficial en inglés está disponible en https: / / wcd.coe.int/ViewDoc. jsp?id $=1011109 \&$ Site $=$ CM\&BackColorInternet $=9999$ CC $\&$ BackColorIntra net=FFBB55\&BackColorLogged=FFAC75; y una traducción privada de la misma en http: / / es.slideshare.net/mariadaza3958/recomendacin-2006-8ct-mtros-consejo-de-europa-traduccin.
} 
de 2012. No olvidemos, finalmente, que nuestra desgraciada experiencia terrorista ha desarrollado un concepto asistencial a la víctima de estos terribles delitos desde hace mucho tiempo, lo que nos da una experiencia en esta materia para afrontar el futuro: en efecto, desde 2011, gracias a la Ley 29 de 2011, de "Reconocimiento y protección integral a las víctimas del terrorismo" (art. 51), existe una oficina pública de asistencia a la víctima de los delitos de terrorismo en la Audiencia Nacional, a cargo del Ministerio de Justicia, que puede contactarse electrónicamente.

La posibilidad de que al lado de instituciones públicas puedan asistir a la víctima organizaciones privadas facilita que muchas organizaciones no gubernamentales puedan dedicarse a este loable fin, porque son menos rígidas y permiten una mayor cercanía con la víctima, siempre que su personal esté realmente especializado; en este sentido, se destacan algunas ONG como, por ejemplo, la Victim Support inglesa o la Weisser Ring alemana.

\section{La organización del acceso.}

Es la concreción del denominado genéricamente derecho al apoyo, y se define en el PLEVict en la creación de unos servicios de asistencia y apoyo a cargo de las Administraciones Públicas y unas Oficinas de Asistencia a las Víctimas (arts. 27 a 33). No entramos en esta cuestión por ser puramente orgánica.

\section{Derechos procesales penales}

El PLEVict es en tema de derechos procesales penales más prolífico, pues establece hasta siete derechos procesales, algunos de ellos a su vez con derechos específicos de concreción y desarrollo, prácticamente todos ellos regulados en la LECRIM, con lo cual existe en muchos aspectos una duplicación normativa clara que en la práctica puede conllevar problemas importantes de interpretación.

Pero el problema más grave no es ese, porque, como veremos, algunos de los derechos que establece no se reconocen a la víctima únicamente cuando es parte procesal, sino que pueden ser aplicados también cuando no es parte todavía o incluso cuando ha decidido no ser parte en absoluto. Ello hace que este apartado sea de muy difícil sistematización, lo que sin duda alguna dificulta su aprendizaje y, sobre todo, su práctica correcta. A continuación, se examinan los derechos procesales penales previstos por el PLEVict. 


\section{Derecho a entender y ser entendida en las actuaciones procesales penales desde la interposición de la denuncia.}

El art. 4 PLEVict, que traspone el art. 3 de la Directiva 2012 / 29 / UE, regula el derecho de la víctima a entender y ser entendida. Este derecho tiene una formulación lingüística discutible, porque en castellano el derecho a entender y ser entendido es, en realidad, el de comunicarse con alguien. Y este puede, perfectamente, ser una manifestación del derecho a ser informado (el propio art. 4, I admite que ello incluye "la información previa"). En nuestra opinión, la literalidad del texto europeo en la transposición no está justificada, pero, dada la regulación legal, debemos entrar en ella. Lo que se prevé en esta norma es precisamente una manifestación del derecho a ser informada que tiene la víctima (contemplado en el artículo siguiente), consistente en poder comunicarse con las autoridades judiciales, fiscales y policiales una vez iniciado el proceso, para lo que habrá recibido información desde el primer contacto con dichas autoridades.

La comunicación interactiva tiene lugar con ocasión de cualquier actuación procesal que se realice desde la denuncia hasta el final del proceso. Este derecho consiste en que la víctima debe recibir comunicaciones orales o escritas por parte de las autoridades ${ }^{5}$ que intervienen en el proceso y también por parte de las oficinas de asistencia a las víctimas, expresando en ellas en lenguaje claro y sencillo el contenido pertinente al acto. Esta comunicación se extiende incluso a su representante legal o a la persona que le asista $^{6}$, si se trata de un menor de edad o persona con capacidad judicialmente complementada. Por lo tanto, tiene derecho a ser informada por escrito y verbalmente en forma transparente.

La prescripción del art. 4, II-c) PLEVict está desubicada, puesto que la víctima puede gozar del acompañamiento, además de su abogado (Exposición de Motivos, apartado V, II, y art. 16), de una persona de su elección desde el primer contacto con las autoridades

${ }^{5} \mathrm{El}$ "Informe al Anteproyecto de Ley Orgánica del Estatuto de la Víctima del Delito" (Consejo Fiscal de la Fiscalía General del Estado, 2013, p. 7), propuso que se añadiera a autoridad, funcionario, pero no ha sido aceptado de momento.

${ }^{6}$ El Informe del Consejo General de la Abogacía, citado en el "Dictamen sobre el anteproyecto de ley orgánica del estatuto de la víctima del delito" (Consejo de Estado, 2014, p. 8), es contrario a esta persona que asiste a la víctima, pues dice que esa función la puede cumplir perfectamente su abogado. 
y funcionarios, es un tema muy importante para ella por el apoyo, la confianza y tranquilidad que le pueda prestar esa persona, pero no es una cuestión de 'entendimiento'.

\section{Derecho a la información desde el primer contacto con las autoridades competentes a partir del momento previo a la presentación de la denuncia.}

El art. 5 PLEVict, que traspone el art. 4 de la Directiva 2012/29/ UE, regula el derecho de las víctimas a la información desde el primer contacto con las autoridades competentes. No cabe duda de que el derecho a la información es, desde luego en los momentos iniciales tras la comisión del crimen y surgimiento del status de víctima para una persona, el más importante.

En este punto, la ley es muy explícita y no requiere de demasiado comentario dado que no son disposiciones complejas, aunque el problema puede estar en su práctica, porque ante la actual saturación de los juzgados de instrucción, imponer una obligación periódica de información a la Oficina Judicial -se supone aunque no se diga que es el órgano competente para ello- que debe actualizarse en cada fase del proceso (art. 5.2), no es fácil de cumplir; salvo que se trate de información escrita que automáticamente se mande al correo electrónico de la víctima por una base de datos, convenientemente elaborada.

El Consejo General del Poder Judicial ha propuesto que esa información se dé por expertos (2014, p. 25), pero su sugerencia no ha sido atendida, quizás porque el legislador entiende que ya está previsto en el art. 30 -implícitamente- al exigir a la autoridad una formación especial, pero no habría sido redundante remarcarlo.

En resumen, este derecho de la víctima consiste en recibir de la autoridad competente información desde el primer contacto que se produzca con ella, sin dilaciones indebidas y adaptada a su persona y al delito cometido, teniendo en cuenta también los daños producidos, sobre las medidas de asistencia y apoyo disponibles para ella; su derecho a denunciar los hechos y el procedimiento pertinente; su derecho a facilitar elementos de prueba a la autoridad; su derecho al asesoramiento y a la defensa jurídica, de confianza o gratuita. Además, las medidas de protección a su disposición y el procedimiento; y su derecho de reparación (indemnizaciones, servicios de justicia restaurativa disponibles) que, como lo indica el Consejo de Estado, debió indicarse también cómo obtener esos 
servicios (2014, p. 16). También, los servicios de interpretación y traducción; las ayudas y servicios auxiliares para la comunicación disponibles, en caso de que los necesite, se supone; el ejercicio de sus derechos si reside fuera de España; los medios de impugnación a su disposición; el modo de contactar con la autoridad judicial y fiscal; cómo obtener el reembolso de los gastos judiciales, lo cual fue añadido al texto original a instancias del Consejo General del Poder Judicial (2014, p. 25); y el derecho a ser notificada del desarrollo del proceso penal en la dirección de correo electrónico o, en su defecto, en una dirección postal/domicilio, que haya indicado la víctima en su solicitud expresa al respecto.

El Ministerio Fiscal ha propuesto que se informe también a la víctima sobre las funciones que realiza el Ministerio Público en el proceso penal que le afectan, especialmente su función tuitiva (2013, p. 8.), petición que no fue atendida.

\section{Derechos específicos de la víctima como denunciante a obtener un resguardo validado y a la asistencia lingüística gratuita y a la traducción escrita.}

El art. 6, que traspone el art. 5 de la Directiva 2012/29/UE, fija los derechos de la víctima como denunciante. Es obvio que todas las personas tienen derecho (art. 24.1 CE) y también la obligación de denunciar un delito, salvo excepción legalmente prevista (arts. 259, 260 y 261 LECRIM), y, especialmente, la víctima. A ello no se refiere este precepto, cuyo título oficial es engañoso. Lo que regula es el derecho a ser asistida por los servicios de intérprete y traducción en el momento de denunciar si no habla el castellano y a recibir un resguardo de la denuncia, aunque debería bastar devolver a la víctima la copia sellada de la misma, en mi opinión ${ }^{7}$.

No se olvide que si la primera autoridad de contacto de la víctima es la Policía al formular la denuncia, entran en juego los derechos de información y comunicación que en esta ley se regulan y estamos comentando, por lo tanto, no se recibirá sólo esa copia escrita, sino mucho más, una vez se haya formulado la denuncia y sea admitida por la Policía.

\footnotetext{
${ }^{7}$ Coincidente con la opinión del "Dictamen sobre el anteproyecto de ley orgánica del estatuto de la víctima del delito" (Consejo de Estado, 2014 p. 16) y con la del Consejo General del Poder Judicial, en el "Informe al anteproyecto de ley orgánica del estatuto de las víctimas del delito" (Consejo General del Poder Judicial, 2014, p. 25), que no ha sido atendida.
} 
Finalmente, téngase en cuenta, porque no podemos entrar en ello aquí, que el Proyecto de Ley Orgánica por la que se modifica la Ley de Enjuiciamiento Criminal para transponer la Directiva 64 de 2010 y la Directiva 13 de 2012, de 22 de mayo de 2012, relativa al derecho a la información en los procesos penales, en trámite parlamentario en estos momentos igualmente, modifica la LECRIM en su art. 1 en temas de interpretación y traducción en los procesos penales. También deben considerarse el art. 3, que modifica la LOPJ en cuanto a la habilitación como intérprete y la Disposición Adicional Única, que regula el Registro Oficial de Traductores e Intérpretes Judiciales de esta Ley Orgánica.

\section{Derecho a ser informado sobre la causa penal.}

El art. 7 PLEVict, que traspone el art. 6 de la Directiva 2012/29/ UE, recoge con detalle el derecho de la víctima a recibir información sobre la causa penal. Se trata de un precepto muy extenso, pero muy importante, porque afecta sobre todo a la víctima que haya decidido no ser parte en el proceso penal, permitiéndole estar informada en todo momento sobre su desarrollo, no sólo a efectos de conocimiento, sino también a efectos de una actuación procesal explícita cuando la ley lo permita, por ejemplo, interponer un recurso.

Para que esa información sea pertinente, la víctima debe pedirlo expresamente mediante la solicitud a que se refiere el art. 5.1, m) (art. 7.1, I PLEVict, de lo que no ha sido informada) ${ }^{8}$. Puede revocarla sin problema alguno (art. 7.2). La exigencia de solicitud previa es razonable si ha sido informada de ello explícitamente la víctima, lo que parece que garantice el art. 5.1, m), citado expresamente en el precepto.

Se notifica en el correo electrónico que proporcione la víctima, o, si no tiene, algo muy difícil de imaginar hoy, en la dirección de correo ordinario indicada en su caso. Es aplicable supletoriamente el art. 162 LEC. Si reside fuera de la Unión Europea y no consta ninguna de esas dos direcciones, la notificación es diplomática (art. 7, III PLEVict).

\footnotetext{
${ }^{8}$ Debería ser informada de ello la víctima expresamente, pero el art. 5 PLEVict no lo recoge, a pesar de haber sido puesto de manifiesto por el "Informe al anteproyecto de ley orgánica del estatuto de la víctima del delito" (Consejo Fiscal de la Fiscalía General del Estado, 2013, p. 9).
} 
La información se refiere estrictamente a resoluciones judiciales, desde los inicios del proceso penal hasta la finalización de la ejecución $\mathrm{y}$, en este último caso, también a las resoluciones de la autoridad penitenciaria. En concreto: Auto denegando el inicio del proceso penal; la sentencia que ponga fin al procedimiento, se supone que se refiere a la definitiva (primera instancia) y a la firme (apelación o casación); autos de prisión y de posterior puesta en libertad del infractor; y la providencia en que se comunique la fuga del imputado, acusado o reo, aunque la redacción legal en este punto del art. 7.1, c) in fine debería mejorarse notablemente, pues es muy confusa y lo dicho en el texto es mucho más claro y preciso. Además: Autos sobre adopción o modificación de medidas cautelares personales cuyo fin fue garantizar la seguridad de la víctima; resoluciones o decisiones de cualquier autoridad judicial o penitenciaria que afecten a sujetos condenados por delitos cometidos con violencia o intimidación y que supongan un riesgo para la seguridad de la víctima; y, en fin, resoluciones durante la ejecución de la pena en caso de condena por determinados delitos muy graves a los que se refiere el artículo 13 (v. infra).

A propósito de lo anterior, conviene tener en cuenta que el lugar y celebración del juicio se notifica por escrito a toda víctima, por lo tanto también a la que no sea parte, por el Secretario, e igualmente el día y lugar de celebración de la vista de apelación (arts. 785.3 y 791.2 LECRIM). Así, el art. 7.1, I es más restrictivo que la legislación vigente en punto al juicio oral de la primera instancia, lo que no es admisible y debe corregirse. Sobre esto advirtieron tanto el "Informe al anteproyecto de ley orgánica del estatuto de la víctima del delito" (Consejo Fiscal de la Fiscalía General del Estado, 2013, p. 10), como el "Dictamen sobre el anteproyecto de ley orgánica del estatuto de la víctima del delito" emitido por el Consejo de Estado (2014, p. 17).

Además, los autos de prisión y de posterior puesta en libertad del infractor, la providencia en que se comunique la fuga del imputado, acusado o reo, y los autos sobre adopción o modificación de medidas cautelares personales cuyo fin fue garantizar la seguridad de la víctima, se notifican a las víctimas de la violencia de género de oficio, por ende, sin necesidad de que la propia víctima lo pida (art. 7.3 PLEVict). De manera impropia se prevé que estas resoluciones judiciales y penitenciarias se hagan también a la víctima que haya decidido ser parte en el proceso (art. 7.1, III), lo que es obvio, porque como parte procesal debe garantizársele en todo caso el principio de contradicción y, en consecuencia, viene notificada de todas las 
resoluciones judiciales que se dicten. Es obvio, igualmente, que se comunican a su procurador. Sobra, por lo tanto, este párrafo, ya que la notificación personal no es necesaria ${ }^{9}$.

No sabemos muy bien por qué la ley no quiere que se notifique la resolución completa, porque eso sería lo adecuado. Pero no, solo su parte dispositiva y un breve resumen del fundamento de la misma (art. 7.1, II). Más trabajo para la Oficina Judicial, sin posibilidad alguna de aumento de medios, ni de recursos humanos ni materiales.

Finalmente, nada dice la ley, pero deberían notificarse a la víctima también aquellas resoluciones o hechos procesales que impliquen un progreso importante en la causa (Consejo Fiscal de la Fiscalía General del Estado, 2013, p. 10), por ejemplo, el hallazgo del bien robado o también un grave contratiempo, verbi gratia, el decreto de una nulidad procesal con retroacción de actuaciones.

\section{Derecho a la traducción e interpretación.}

El derecho de la víctima a la traducción e interpretación se reconoce en el art. 9 PLEVict, que traspone el art. 7 de la Directiva 2012/29/UE. Se trata de un desarrollo del art. 231 LOPJ específicamente para la víctima. Se regula en la actualidad en los arts. 398 y 762-8 ${ }^{\mathrm{a}}$ LECRIM, entre otras normas aplicables, incluida la profusa normativa internacional y supranacional [véase, art. 14.3 del Pacto Internacional de Derechos Civiles y Políticos (1966); el art. 6.3, a) y e) del Convenio Europeo de Derechos Humanos y la Directiva 64 de 2010]. No se olvide, tampoco, la transposición de la Directiva 64 de 2010, actualmente en tramitación en el Parlamento español, que modifica la LECRIM en estos mismos aspectos (véanse, "Proyecto de ley orgánica por la que se modifica la ley de enjuiciamiento criminal para transponer la Directiva 64 de 2010" y la Directiva 13 de 2012).

No deben hacerse comentarios superfluos porque la disposición es clara e importante en un país tan cosmopolita como España. Si no se habla ni entiende la lengua judicial española (español o castellano y, en su caso, lengua autonómica), poca información se puede recibir y probablemente ningún derecho pueda ejercerse de forma correcta,

\footnotetext{
${ }_{9}$ Para el Consejo General del Poder Judicial también es criticable. Véase, "Informe al anteproyecto de ley orgánica del estatuto de las víctimas del delito" (2014, p. 27).
} 
lo que implica según la jurisprudencia internacional y española una clara vulneración del derecho de defensa y del derecho al proceso con todas las garantías, si se trata del imputado o acusado, pero, si se trata de la víctima, el derecho constitucional en juego es el derecho a la tutela judicial efectiva (TEDH, Kamasinski vs. Austria, 1989 y la Sentencia 71 de 1988 del Tribunal Constitucional, entre otras muchas), de ahí la obligación de coadyuvar al pleno ejercicio de los derechos de la víctima ofreciéndole los servicios de traducción e interpretación.

El derecho se extiende a quienes hablan o comprenden el castellano o la lengua autonómica en su caso, pero tienen dificultades y limitaciones auditivas o de expresión oral, para que queden cubiertos los sordos, mudos y ciegos, así como a las personas con discapacidad que afecte a esos sentidos (art. 9.1, a)-II). El servicio se presta a una persona estrictamente por ser víctima de un delito. No importa que sea o no parte, no importa que comparezca como testigo. Pero la aplicación preferente del art. 9, como es lógico, se produce cuando la víctima no sea parte. Tampoco es relevante ante qué autoridad (Policía, Fiscalía, Juez) declara o de qué autoridad recibe información, lo que incluye a los servicios de asistencia y apoyo.

El derecho consiste en contar con un intérprete gratuito y en tener una traducción gratuita. El primero, para cuando tenga que declarar o el acto sea oral y necesite escuchar y participar, bien presencialmente, que es lo aconsejable para garantizar mejor los derechos constitucionales del imputado o acusado, bien por videoconferencia (at. 9.2); el segundo, para cuando deba recibir determinados escritos o tenga que presentarlos, permitiendo la ley, por cierto, que no se traduzca el escrito y que éste sea sustituido por un resumen oral de su contenido (art. 9.3).

La traducción gratuita parece limitarse por la ley a las resoluciones previstas por los arts. 7.1 y 12, y a la información que resulte esencial para el ejercicio de los derechos, lo cual puede ser problemático en la práctica si ese resumen no es correcto o la traducción no es buena, pudiendo presentar la víctima una moción para que se considere esencial un documento (art. 9.1, b) y c). Ahora bien, ¿gratuitamente también en este último caso? Si no lo es, al menos provisionalmente, el derecho es dudosamente ejercitable. Por lo tanto, la interpretación es un derecho que debe reconocerse a la víctima durante todos los actos orales en los que deba intervenir y por toda 
su extensión, mientras que la traducción es un derecho concreto, para determinados actos escritos.

La negación de este derecho por la Policía o por el Juez es recurrible conforme al art. 9.4 y 5 PLEVict. ¿Y si lo deniega la Fiscalía? Este aspecto no está resuelto, por lo que debería ser equivalente a cuando lo deniega la Policía. La ley es, finalmente, muy generosa en la extensión de este derecho, como demuestra la propia lectura del precepto. Eso honra al Ministerio de Justicia, pero el Ministerio de Hacienda se va a encargar de que la ley no se cumpla, porque una extensión tan amplia del derecho de traducción e interpretación como la regulada en este precepto cuesta mucho dinero, y la ley se autoimpone un costo de aplicación cero (Disposición Final $6^{\mathrm{a}}$ ). Sin comentarios, por tanto.

\section{Derecho de la víctima a participar en el proceso penal como parte ejerciendo la acción civil e interponiendo la pretensión penal.}

Esta potestad, regulada en el Título II PLEVict se descompone, a su vez, en varios derechos, algunos de los cuales son propios de las víctimas que sean parte y otros de las víctimas que no sean parte en el proceso penal, existiendo finalmente otros que se afectan por igual, tanto si es parte como si no. Llamamos la atención, por lo tanto, respecto a lo indicado supra en cuanto a la dificultad que esta técnica legislativa comporta para el intérprete.

Pero antes de entrar en materia debemos fijarnos en una cuestión lingüística: la ley habla del derecho de participación activa de la víctima en el proceso penal, sin duda alguna influenciada totalmente por la Directiva 29 de 2012. En puridad, el derecho de participación activa debería ser en España su derecho a ser parte penal y civil en el proceso penal, pero, entonces, el PLEVict no se entendería siempre bien, porque su mayor impacto está previsto para cuando la víctima decide no hacerse parte. Por ello, habría que distinguir cuando la víctima sea parte, de cuando no lo sea, sabiendo que en varias ocasiones el precepto se aplica a ambos supuestos, lo que remarcaremos específicamente. Así y en concreto, debemos analizar estos derechos desde los siguientes puntos de vista:

\section{Como parte procesal.}

El PLEVict desarrolla el derecho genérico de participación en cuatro derechos específicos en sus arts. 11 y 14 a 16: 
Derecho a una participación activa en el proceso penal como parte penal y civil.

El primero hace referencia a la participación activa en el proceso penal y se regula en el art. 11 PLEVict, que traspone el art. 10 de la Directiva 2012/29/UE. Quizás esta norma podía haberse incardinado en los arts. 109 bis y 110 LECRIM aprovechando la Disposición Final $2^{a}$ de dicha futura ley. También modificando el 761 LECRIM. Por lo demás, su contenido es claro, pues constitucionalmente la víctima tiene derecho a ser parte acusadora particular en el proceso penal y, por lo tanto, esta norma lo que hace es confirmarlo (apartado a), añadiendo un derecho obvio si es parte: el de aportar pruebas e información ante la autoridad pública de persecución (apartado b).

La regulación de cómo se persona y comparece adquiriendo la cualidad de parte es la prevista en nuestra LECRIM con las realidades prácticas que en los últimos tiempos se han producido a la vista del art. 761.2: denuncia manifestando su voluntad de ser parte, querella clásica, escrito específico o comparecencia apud acta.

Pero no se resuelve el término ad quem, es decir, hasta cuándo puede personarse como parte y hasta cuándo puede aportar pruebas e informar en la investigación. Si aplicamos la regla general hoy vigente, el momento procesal último para personarse debería ser el inicio del acto del juicio oral, compareciendo personalmente en la sesión, puesto que tanto en el proceso penal ordinario por delitos más graves como en el proceso abreviado, y, por ende, en todos los demás por delito, la acusación ya se ha presentado (con base, reconozco de difícil interpretación conjunta, en los arts. 110 y 785.3 LECRIM). Y, para aportar pruebas e informar no siendo parte, el momento procesal último debería ser antes de que se dicte la apertura del juicio oral, pero no es claro, por lo que debería decirse específicamente (Consejo General del Poder Judicial, 2014, pp. 3031). Sin embargo, esto va a cambiar, acogiendo la más moderna jurisprudencia, con la introducción del nuevo art. 109 bis LECRIM por la Disposición Final $2^{a}$ PLEVict.

La importancia del art. 11, b) reside, por ello, desde otro punto de vista, en el caso de que la víctima haya decidido, o todavía no lo tenga claro, no ser parte en el proceso penal, pues, entonces, su derecho a participar inicialmente sí tiene sentido, ya que la ley le permite colaborar con la investigación desde su punto de vista, 
de manera que sea más eficaz para garantizarle en el futuro una adecuada restitución, reparación e indemnización por los daños físicos, psíquicos y morales sufridos. Se eleva a rango de ley lo que ya sucede en la realidad, pues la Policía siempre busca la colaboración de la víctima y recoge como material probatorio todo lo que esta le proporciona que pueda servir a ese fin.

Derecho al reembolso de gastos.

El art. 14 regula el derecho al reembolso de gastos de las víctimas y traspone el art. 14 de la Directiva 2012/29/UE. Un derecho lógico, del que habrá sido previamente informada (art. 5.1, 1) PLEVict), porque, dado que forzosamente se ha visto ubicada en el estatuto jurídico de la víctima de un delito, no puede exigírsele que, además, tenga que pagar los gastos y costas procesales derivados de su participación en el proceso. Para ello es necesario que la sentencia condene en costas y que el acusado haya sido condenado, a instancia de la víctima, por delitos por los que el Fiscal no hubiera acusado, tras la revocación del sobreseimiento gracias a un recurso interpuesto por la víctima.

Debe entenderse que no se considera entre esas resoluciones la decisión del Ministerio Fiscal de no continuar adelante con sus diligencias de investigación internas ${ }^{10}$, para lo que tiene un plazo de seis meses una vez abiertas, pues la víctima puede, en tales casos, denunciar el hecho ante el Juez (art. 5.2 del Estatuto Orgánico del Ministerio Fiscal de 1981).

Dada la redacción legal, el derecho al reembolso debe ser aplicable tanto si la víctima ha sido parte como si no. Aquí se emplea el derecho a participar en el doble sentido a que nos referíamos anteriormente, lo que dificulta enormemente la ubicación sistemática de este precepto. En la medida en que su importancia práctica es mayor cuando se ha sido parte, preferimos optar por esta vía.

La víctima deberá justificar los gastos procesales (v.gr., consultas previas con un abogado, preparación de alguna prueba). Se supone que el procedimiento de reembolso deberá establecerse reglamentariamente, salvo que se acuda directamente a las normas sobre tasación y exacción de costas para su pago. Esta norma hay

${ }^{10} \mathrm{El}$ "Informe al anteproyecto de ley orgánica del estatuto de la víctima del delito" del Consejo Fiscal de la Fiscalía General del Estado, (2013, p. 17), pidió sin éxito alguno que se aclarara este punto. 
que relacionarla con lo dispuesto en el art. 126.2 del Código Penal, reformado a su vez por la Disposición Final $3^{\mathrm{a}}$ de esta ley orgánica.

\section{Derecho a la Justicia restaurativa.}

El importante art. 15 establece el derecho de la víctima a los servicios de justicia restaurativa y traspone el art. 12 de la Directiva 2012/29/UE. No podemos entrar aquí a desarrollar el concepto, el contenido, las modalidades, los requisitos, el procedimiento, la resolución, la ejecución y los efectos de la Justicia restaurativa (Barona, 1999; Barona, 2009 b; Castillejo Manzanares \& Benavente, 2011, pp. 501 y ss.). Únicamente debemos fijarnos en lo que atañe a la víctima, porque para la víctima lo que importa en la mayor parte de los casos es la reparación civil y no la condena penal del autor del delito que ha sufrido ${ }^{11}$. Y una manera de ser reparado rápidamente y sin mucha complicación es a través de la mediación penal, la manifestación más importante, aunque no la única, de la Justicia restaurativa ${ }^{12}$.

La ley abreesta posibilidad, aunque para su plena implementación se requiere, primero, que la mediación penal se autorice en general para adultos ${ }^{13}$ por una ley, lo que de momento no es el caso en España ${ }^{14}$ y, segundo, un desarrollo reglamentario adecuado. Qué

${ }^{11}$ Mi papel como miembro del grupo de trabajo del Ministerio de Justicia encargado de elaborar un estatuto integral de la víctima en 2013, habiendo asistido en solo dos ocasiones, se contrajo a la redacción de un borrador de texto legal sobre la Justicia restaurativa. Lo tengo en mi poder y fue enviado al Ministerio de Justicia por e-mail el día 6 de enero de 2013. Constaba de 44 artículos, muchos de ellos necesitados de complementación con lo dispuesto en el Anteproyecto de nueva LECRIM que en esos momentos se estaba elaborando en el seno del mismo Ministerio, pero que yo no conocía. Se seguía a rajatabla la obligación de transposición de la Directiva 29 de 2012. Obviamente no ha sido publicado. En líneas generales puedo decir que no ha sido tenido en cuenta por el Ministerio. Hago referencias a él en mi artículo "Notas sobre la Justicia procesal (alternativa, negociada, transaccional, restaurativa o reparadora). Un nuevo subsistema de Justicia para aliviar al sistema de Justicia Judicial" (Gómez, 2015). Tampoco he sido consultado como experto cuando el Ministerio decidió publicitarlo selectivamente en 2013.

${ }^{12}$ Sobre las últimas novedades en cuando a la mediación penal en España, véase, Armengot Vilaplana, (2014, pp. 91 y ss.).

${ }^{13}$ Para menores delincuentes ya lo está por el art. 19 de la Ley Orgánica 5 de 2000, reguladora de la responsabilidad penal de los menores.

${ }^{14}$ Como la reforma integral de nuestro enjuiciamiento procesal penal está ahora paralizada, va a ser el Estatuto Jurídico de la Víctima del Delito, sede poco adecuada, porque no es la norma básica de nuestro proceso penal, hoy 
duda cabe que si eso no ocurre definitivamente, o mientras tanto, las disposiciones de la Ley 5 de 2012, pueden resultar parcialmente aplicables.

Para que la mediación sea admisible deben cumplirse los requisitos del art. 15.1, que no son ni pocos, ni en algún punto fáciles de satisfacer: La mediación no debe estar legalmente prohibida a causa del delito cometido, lo que sucede explícitamente en casos de violencia de género (art. 44.5 Ley Orgánica 1 de 2004); el autor del delito debe haber reconocido los hechos esenciales de los que deriva su responsabilidad y prestar su consentimiento para la mediación; la víctima, una vez ha sido 'exhaustivamente informada' (una evidente exageración conceptual), debe estar también de acuerdo; y, muy importante, el desarrollo de la mediación no debe entrañar riesgos para la seguridad de la víctima ni causarle más daño, exigencia no prevista en la Directiva 2012/29/UE, como destaca acertadamente el "Dictamen sobre el anteproyecto de ley orgánica del estatuto de la víctima del delito" (Consejo de Estado, 2014, p. 21).

No resuelve el legislador español si la mediación será admisible en todos los delitos o sólo en algunos de ellos, porque en este caso no proporciona un listado. Obviamente, lo que se diga en el procedimiento de mediación es confidencial. Los mediadores están sujetos a secreto profesional y los resultados obtenidos no podrán ser difundidos sin el consentimiento de ambas partes (art. 15.2). La mediación es siempre voluntaria, razón por la que el consentimiento para participar en ella es revocable en cualquier momento por cualquier parte (art. 15.3).

Finalmente, y es importante porque no se ha transpuesto la Directiva 2012/29/UE aquí y ello es ilegal, el acuerdo alcanzado conforme al art. 12.1, d) de la misma, podrá ser tenido en cuenta en cualquier otro proceso penal; así lo denuncia expresamente el "Informe al anteproyecto de ley orgánica del estatuto de la víctima del delito" (Consejo Fiscal de la Fiscalía General del Estado, 2013, p. 18). De mantenerse en España la regulación del PLEVict, ello no será posible, al menos de inmediato.

La novedad fundamental de esta norma es que la víctima pueda ser reparada rápidamente y sin mucha complicación a través de

en tramitación parlamentaria, la norma habilitante de la mediación penal en nuestro país, que requerirá sin duda desarrollo reglamentario, el mínimo imprescindible. 
la mediación penal, la manifestación más importante, aunque no la única, de la Justicia Restaurativa. El derecho a la reparación es tan relevante que, en realidad, es el único derecho que en definitiva le importa, sin que se malinterpreten estas palabras. Si es parte, lucha ella misma por este derecho, si no lo es lo asume el Ministerio Fiscal con cierta intervención de la víctima. Consiste, en su caso, en recuperar el bien mueble intacto (restitución), ser reparada económicamente en el daño causado, bien en su persona (física o psíquicamente), bien en sus bienes y derechos (económicos y morales), e indemnizada por los perjuicios sufridos.

Como en suma se trata de obtener una tutela reparadora y restaurativa de sus bienes y derechos económicos, la cuestión es atender al patrimonio del autor del delito $y$, si no tiene, o complementariamente, a fondos públicos de indemnización, en el supuesto obviamente de que existan. Pero para lograr del autor la restauración/ reparación se requiere en el proceso penal moderno de instituciones que equilibren mejor las disfunciones del sistema, de manera tal que todos paguen un precio, la víctima cediendo en sus pretensiones y el autor del delito obteniendo una ventaja jurídica frente a la consecuencia jurídica del delito que le habría correspondido de aplicarse la ley estrictamente.

El diseño del sistema compensatorio de reparación exige hoy la articulación de órganos públicos de mediación, conciliación y restauración, y de organismos privados con fines específicos en la materia, por ejemplo, las instituciones del ADR, conciliación, acuerdo, mediación civil y mediación penal (sobre ella, específicamente infra). No todos están ni permitidos ni desarrollados, pero el Estatuto Jurídico de la Víctima del Delito va a darles un gran impulso.

Hasta que ello sea una realidad, la víctima parte de una posición relativamente ventajosa frente a actos de favorecimiento de la situación jurídica del imputado y/o acusado en una negociación, porque, para que ello sea posible, debe estar completamente reparada, lo que condiciona, parece que razonablemente, la eficacia de la institución alternativa. Se articula mediante instituciones en los que la víctima influye en las alternativas a la persecución (principio de oportunidad), en la negociación sobre la pena (conformidad), y en la continuidad en la ejecución de la pena (suspensión).

Muchos de estos derechos están ya reconocidos en la ley, aunque sea en forma deficiente. Lo que va a hacer el Estatuto Jurídico de 
la Víctima del Delito es recogerlos, mejorarlos y ampliarlos para colocar a la víctima en el Siglo XXI, en todos aquellos aspectos en que en España, con su situación particular ideal de poder ser parte acusadora penal y parte civil, pueda resultar más beneficiada, en especial, si decide no ser parte en el proceso penal. Entramos en este tema a continuación. La reparación e indemnización (Justicia Restaurativa) es la manifestación más concreta, una vez ha ejercido la víctima su derecho de acción, del derecho a la tutela judicial efectiva, porque facilita de manera adecuada su pronta satisfacción (Galain, 2010, pp. 87 y ss.).

De momento podemos hablar en España de principio de oportunidad (alternativas a la persecución) o de Justicia negociada (conformidad), tanto si es parte como si no, porque el acuerdo final requiere de su concurso. Una institución como la mediación penal todavía no está permitida en España, salvo en menores como indicamos, y en algunos casos también recogidos, como en temas de violencia de género, está expresamente prohibida (Cervelló, 2013, pp. 22 y ss.; De Vicente, 1997, pp 173 y ss.; Ferreiro, 2005, pp. 413 y ss.; Garciandía, 2012, pp. 1005 y ss.; Quintero, 2011, pp. 501 y ss.; Varona, 2000, pp. 37 y ss.; Varona, 2011, pp. 13 y ss.). En el extranjero hay diferentes posibilidades, distinguiéndose claramente los países anglosajones de los demás (Tamarit, 1994, pp. 21-48).

En su articulación, no debe caerse en el error de querer hacer amigos al delincuente y a la víctima (Fairén, 1992, p. 28). Se trata de otra cosa, y ni la amistad es lo principal, ni necesaria en este punto. Tampoco atendemos a una posible culpa de la víctima en la producción del hecho delictivo de cara a mitigar o impedir su restauración. Este apasionante tema sustantivo (Cancio, 1998, pp. 18-22; Silva, 1993, pp. 28 y ss.), en el que no podemos entrar, debería tener repercusión en la fase de restauración de la víctima, porque, al fin y a la postre, estamos ante un caso en el que la víctima es también autor (por ejemplo, el dueño del bar que sirve gratuitamente alcohol a una persona, copa tras copa, habiendo apostado con ella sobre su resistencia y capacidad para beber un litro de whiskey, siendo ingresada al día siguiente como consecuencia del alcohol ingerido en un hospital en donde perdió parte del estómago y del intestino delgado tras una complicada operación quirúrgica, ¿es responsable penalmente sólo él del hecho, o lo es también la víctima que se embriagó?), pero nuestro ordenamiento actual nada dice al respecto. El Estatuto Jurídico de la Víctima del Delito sí prevé una devolución 
de las ayudas recibidas por la víctima dándose determinados requisitos, entre los que no se recoge este (Gómez, 2014, pp. 371 y ss.).

Pero la vía más efectiva es hoy, y por mucho tiempo al parecer, el ejercicio de la acción civil acumuladamente a la penal, de manera que, como víctima perjudicada, pueda instar su reparación directamente (Fernández, 2004, pp. 223 y ss.). La razón de esta regulación especial reside en que la mediación, como institución autocompositiva que requiere una implicación directa, voluntaria y consciente de las partes enfrentadas, implica un cambio de perspectiva en la manera de resolver el conflicto que está detrás de todo delito entre su autor y la víctima, que afecta a muchas instituciones procesales, incluido, obviamente, el procedimiento, pero, sobre todo, a los principios más importantes del proceso penal y, desde luego, a una nueva manera de entender el Estado y el ejercicio del ius puniendi (Barona, 2010, pp. 229 y ss.). En España, además, debe vigilarse especialmente que las competencias normativas atribuidas a las comunidades autónomas en materia de mediación sumen y no resten en ese nuevo entendimiento de cómo resolver la cuestión jurídica que está detrás.

No olvidemos, a la hora de analizar la futura mediación penal que se va a tener que regular en España, que si analizamos la cuestión en clave histórica y observamos los países que nos rodean jurídicamente, el desarrollo de la mediación se corresponde con el desarrollo de los derechos de la víctima del delito, pero que en nuestro país, precisamente al poder ser parte la víctima en el proceso penal como acusadora particular, muchos de los problemas que se pretenden resolver con la mediación, se resuelven perfectamente en el seno del propio proceso penal, con lo cual, a priori, su impacto va a ser mucho menor. Pero, también es cierto que en España su espacio no va a quedar asegurado mientras el proceso penal se desarrolle tan lentamente como sucede hoy en día, y quienes públicamente intervienen en él contribuyan decisivamente a ese pésimo funcionamiento. En otras palabras, si el sistema de Justicia judicial no funciona en España, entonces hay que buscar alternativas y la mejor hoy en día es la Justicia procesal (la no judicial), destacando entre sus instituciones la mediación penal. El problema no va a ser, pues, de articulación, sino de encaje (Gómez, 2015, pp. 169 y ss.).

La clave de ello reside en que la mediación penal es la vía idónea para que la víctima obtenga su reparación, que como hemos afirmado en páginas precedentes es la cuestión que más preocupa a la 
víctima en el fondo. Su funcionamiento se justifica de manera fácilmente entendible. Se desacraliza la acción penal, el proceso penal y su amenaza (la pena) deja de existir, al menos momentáneamente, y la contienda se entabla en forma diferente, adoptando la forma de reconocimiento de un conflicto por ambas partes, en el que una persona ha causado un daño a otra, que debe ser, ante todo, reparado de una manera personalizada y concreta en función de su entidad.

La mediación penal se desarrolla fuera del proceso penal, pero su decisión incide directamente en él, porque, si hay acuerdo, implica su terminación, al menos parcialmente. Esta mediación, llamada intraprocesal porque el proceso penal ya está en marcha y todavía no ha terminado mediante sentencia firme, es la más importante en la práctica, porque es lo usual, dado que los delitos públicos exigen su persecución por el principio de necesidad ${ }^{15}$.

El mediador no es un juez, ni un fiscal, ni debería ser un abogado penalista, ni siquiera un jurista, aunque no nos opongamos a que sea un abogado. Pero parece papel más para expertos, por ejemplo del campo de la criminología o de la psicología social. Su función principal no es llegar al acuerdo, que es muy importante porque si fracasa el proceso penal resultará más largo y complejo que si no hubiera tenido lugar, sino garantizar que la negociación se produce en términos de igualdad, para que el autor del delito no aproveche la ocasión para victimizar todavía más a la víctima.

Obtenida la reparación, la víctima deja de tener interés en el proceso penal, que seguirá en función del delito cometido y de la negociación alcanzada, y siempre que el control judicial sea satisfactorio, para llegar a una condena, probablemente, del autor del delito, mucho más satisfactoria para éste o, al menos, no tan importante como la que habría correspondido de no haberse alcanzado la mediación, de manera que las funciones constitucionales resocializadora y rehabilitadora de la pena se cumplan mejor. Colaborar con la Justicia y reparar a la víctima siempre debe ser, al menos, una atenuante, y en España así es (art. 21.5 CP).

\footnotetext{
${ }^{15}$ También tiene importancia la mediación en fase de ejecución penal, porque en España tenemos normas que condicionan beneficios penitenciarios e incluso la propia libertad a la reparación de la víctima (arts. 4.4, 80, 81, 88, etc. $(\mathrm{P})$, pero para la víctima puede ser demasiado tarde, de ahí que los esfuerzos mayores deban concentrarse en la mediación intraprocesal.
} 
El juez penal controla el acuerdo de mediación. La vía más común es, si la ley permite que el proceso deje de existir, la del sobreseimiento libre y, si el juicio oral ya está abierto, la utilización de la conformidad (de momento, a salvo de que la futura ley introduzca una vía propia) y su reflejo en la sentencia conforme a las normas aplicables, en lo que ahora no entramos.

Resulta por ello absolutamente imprescindible, como decíamos supra, que la futura ley de mediación penal regule, mediante un listado de numerus clausus, qué delitos permiten acogerse a esta solución alternativa, dado que no pueden ser todos porque socialmente ello sería reprochable; recordemos, por ejemplo, que en casos de violencia de género, como consecuencia de ese sentir social que recoge la Política Criminal del Gobierno, la mediación penal está hoy prohibida legalmente (art. 44.5 Ley Orgánica 1 de 2004). Política criminal, principio de legalidad y principio de oportunidad juegan aquí un papel distinto a la persecución judicial del delito, pero no por ello dejan de existir como principios esenciales del proceso penal y de la mediación penal; este es, por cierto, uno de los grandes temas que se discuten a la hora de autorizar la mediación penal en España: la postura doctrinal mayoritaria es no permitirla para todos los delitos, sino establecer límites derivados de la gravedad de los hechos o de los bienes jurídicos protegidos (Barona, 2010, pp. 242246). Si atendemos además a las víctimas especialmente vulnerables que reconoce el futuro Estatuto Jurídico de la Víctima del Delito, esta cuestión tiene una importancia crucial, pues ante ellas la sensibilidad social es más elevada.

No considero apropiada la mediación cuando hay un único autor y numerosas víctimas (terrorismo, narcotráfico, etc.), por resultar demasiado difícil de manejar. De ahí que la futura ley de mediación penal debe prever también causas objetivas de exclusión de la mediación. Tampoco cuando el autor del delito es insolvente, para lo que su capacidad económica deberá determinarse antes de la mediación, porque entonces la reparación de la víctima, el fin principal de la mediación penal, es imposible y únicamente saldría beneficiado el autor del delito, lo que sería, además de injusto, inmoral.

Asimismo, debe concretarse la voluntariedad de la mediación, de manera que por esta razón nunca pueda ser impugnada por nulidad. Por ello, debe regularse en qué términos se entiende que el autor ha reconocido los hechos esenciales de los que deriva su responsabilidad y en qué términos debe prestar su consentimiento para 
la mediación. Igualmente ha de preverse específicamente, como es obvio, en qué términos la víctima debe prestar su conformidad para la mediación. También, es consecuencia de la voluntariedad y debe, por ello, regularse que no cualquier revocación será admisible, estableciéndose causales concretas, para que la Justicia no esté en manos del capricho.

La confidencialidad, a la que nos hemos referido supra, debe ser regulada expresamente y, sobre todo, castigada penalmente su vulneración por el mediador. La vulneración por parte del autor del delito debería implicar la pérdida de beneficios procesales y sustantivos, y, por parte de la víctima, se debería tener por no hecha, quedando a expensas del proceso penal su reparación. Se trata, en suma, de garantizar a toda costa el principio de la presunción de inocencia del art. 24.2 CE.

\section{Derecho a la Justicia gratuita.}

Finalmente, se reconoce en el art. 16 -que traspone el art. 13 de la Directiva 2012/29/UE- el derecho de la víctima a la Justicia gratuita. Con base en los arts. 14, 24.1 y 119 CE se establece un derecho de acceso gratuito a la justicia de la víctima. Si decide ser parte en el proceso, se aplican sin problema alguno las disposiciones pertinentes de la LECRIM y la ley 1 de $1996^{16}$, pero el art. 16 es más efectivo si se aplica a la víctima que decida no ser parte, porque entonces es cuando realmente puede ejercer los derechos que la ley le concede no siendo parte con plenas garantías de asesoramiento jurídico sobre los mismos. La solicitud se presenta ante el funcionario o la autoridad que le haya proporcionado la información o ante la Oficina de Asistencia a las Víctimas.

Por lo demás, el procedimiento continúa ante el Colegio de Abogados. Pero esto no es correcto, porque también debe intervenir el Colegio de Procuradores, dado que el PLEVict no limita ningún derecho de los reconocidos en el art. 6 ley 1 de 1996; por lo tanto, la víctima tiene derecho a todo el contenido del beneficio de asistencia jurídica gratuita fijado legalmente, especialmente, a todos los que realmente le son útiles, a saber: Asesoramiento y orientación gratuitos previos al proceso; defensa y representación gratuitas por abogado y procurador en el procedimiento judicial;

${ }_{16}$ Por cierto, está pendiente de aprobación parlamentaria la nueva Ley de Asistencia Jurídica Gratuita. Habrá que estar al tanto de sus disposiciones aplicables para la víctima. 
exención del pago de tasas judiciales, así como del pago de depósitos necesarios para la interposición de recursos; y, asistencia pericial gratuita. A ella hay que añadir la exención de pago a los testigos que declaren a su cargo, en consonancia con la interpretación práctica al uso y jurisprudencia sobre la Ley 1 de 1996 (Gómez, 1996, pp. 1579-1587).

\section{Sin ser parte.}

A pesar de su ubicación, y teniendo en cuenta la advertencia anterior sobre las grandes dificultades de sistematización de este tema, los siguientes tres derechos específicos de participación en el proceso penal no son tales, porque la víctima no es parte en el proceso penal, de ahí que debamos distinguirlos de los anteriores. Es cierto que, una vez cumplido el derecho, la víctima tiene una opción de intervenir o participar en el proceso penal, por ejemplo, interponiendo un recurso, pero si tiene este derecho es precisamente porque no es parte.

Derecho a que se le comunique el auto de sobreseimiento y a impugnarlos

El primer derecho de la víctima que decide no ser parte es el de comunicación y revisión del sobreseimiento de la investigación a su instancia, de acuerdo con el art. 12 PLEVict, que traspone el art. 11 de la Directiva 2012/29/UE. Esta norma, que hay que poner en relación con el art. 636 LECRIM, también reformado por el PLEVict en su Disposición Final 2a , es importante, porque evita el desamparo judicial de la víctima, al menos en una primera fase del proceso, pues es informada de que el juez ha dictado auto de sobreseimiento, libre o provisional, en la causa por el delito que ella ha sufrido. La paralización perjudicial para la víctima se remedia concediendo a la misma el derecho al recurso.

Los autos de sobreseimiento se notifican siempre a las víctimas directas a estos efectos, lo hayan pedido o no. Por eso, no aparecen ya recogidos en el art. 7.1 PLEVict, pues se daba una contradicción aparente ya que en un precepto tenían que haberlo pedido expresamente y en el otro no. La comunicación se produce a la víctima que haya denunciado el hecho, y al resto de víctimas directas que, no habiéndolo denunciado, resulten conocidas y se sepa su domicilio. También a las víctimas indirectas en caso de fallecimiento o desaparición de la persona (en)causada por el delito, conforme a lo ya explicado (art. 12.1, I y II). 
La limitación establecida al permitir al juez prescindir de la comunicación a los familiares de la víctima muerta o desaparecida no es ajustada al art. 11 de la Directiva 2012/29, que no establece tal límite. Como es restrictiva, se puede decir que la transposición no es ajustada a la norma comunitaria ${ }^{17}$. Los términos 'esfuerzos desproporcionados' presentan dificultades interpretativas más que evidentes por su carácter subjetivo (Consejo de Estado, 2014, p. 19).

El recurso procedente es el fijado por la Ley de Enjuiciamiento Criminal, generalmente apelación (art. 779.1-1 ${ }^{\text {a }}$ LECRIM, modificado por el PLEVict), pero también es posible casación en los casos del art. 848, II (art. 636 LECRIM, modificado recordemos por el PLEVict). Se tramita, por lo tanto, conforme a sus normas sin especialidad alguna.

Pero el plazo debería ser el común a todas las partes (cinco días, si entendemos aplicable el art. 212 LECRIM; o diez días si entendemos aplicable el art. 790.1 LECRIM) y no el de 20 días, tanto si la víctima ha sido parte como si no que propone el PLEVict (arts. 636, VI y 779.1-1 $1^{a}$ último párrafo LECRIM, modificados por el PLEVict). La razón que está detrás de esta ampliación sólo se podría justificar respecto a la víctima que no haya sido parte, porque entonces necesitará más tiempo para conocer la causa y, ante todo, buscar abogado, pero es difícilmente creíble que una víctima informada del proceso contra su agresor no sepa cómo están las cosas, con lo que no necesitaría tanto tiempo. Y la víctima que hasta aquí no ha querido saber nada del proceso penal, seguirá sin querer saber nada con toda seguridad, por mucho que lamente el sobreseimiento y aumente su desconfianza en la Justicia (Consejo General del Poder Judicial, 2014, pp. 33-34).

No se exige que previamente se persone (art. 12.2), por lo que su personación ante el juez o tribunal se produce compareciendo e interponiendo directamente el recurso, pero debe postularse correctamente, ya que la ley no prevé, ni puede prever excepción alguna al respecto tratándose de recursos. Esto significa que la víctima debe estar asistida por abogado y procurador. Es carga suya,

\footnotetext{
17 Los Consejos piensan lo mismo, v. "Informe al anteproyecto de ley orgánica del estatuto de las víctimas del delito" elaborado por el Consejo General del Poder Judicial (2014, pp. 32-33; Gómez, 2014); y el “Dictamen sobre el anteproyecto de ley orgánica del estatuto de la víctima del delito", emitido por el Consejo de Estado (2014, p. 19).
} 
si va a recurrir, resolver el tema de su postulación, sin perjuicio de su derecho a la asistencia jurídica gratuita.

Derecho a recurrir resoluciones dictadas durante la ejecución de la pena.

El segundo derecho es el derecho de la víctima a participar en la ejecución de la pena, reconocido en el art. 13, una importante novedad legislativa que no viene exigida por la Directiva 2012/29 / UE, puesto que nada dice al respecto, aunque la víctima deba ser informada de la causa, lo que incluye la ejecución, conforme al art. 6 , y deba ser informada específicamente de la puesta en libertad o fuga del penado (art. 6.5). Tampoco existe norma similar en ninguno de los países de nuestro entorno cultural influyentes jurídicamente. Este precepto, de hecho, fue el único motivo de discrepancia en el seno del CGPJ, como puede verse en el Voto particular al "Informe al anteproyecto de ley orgánica del estatuto de las víctimas del delito" (Consejo General del Poder Judicial, 2014, pp. 3-13); en suma, lo que proponen los discrepantes es que no se altere el actual sistema porque el cumplimiento de las penas es potestad exclusiva del Estado, y que, por lo tanto, solo el penado y el MF puedan recurrir las decisiones del JVP, como ocurre ahora.

Su introducción puede radicar en la jurisprudencia del Tribunal Supremo español, que afirma modernamente que la pena también tiene, al lado de su finalidad constitucional de resocialización, una finalidad retributiva, lo que daría pie a la intervención de la víctima [Sentencias del Tribunal Supremo números 12 de 2011 $(R J \backslash 2011 \backslash 324)$ y 783 de $2012(R J \backslash 2012 \backslash 9869)]$.

Estamos ante una norma importantísima, muy extensa, pero de contenido fácilmente explicable, aunque no indiscutible, ni justificable sin reparos. No olvidemos que la jurisprudencia ha apoyado la exclusión legal de la participación de la víctima en la fase de ejecución del proceso penal hasta ahora, porque no tiene derecho constitucional alguno a ello ${ }^{18}$. Téngase en cuenta que si se ha mantenido esa postura por nuestros tribunales no es porque les diera igual qué pensara la víctima, o porque considerase que la tutela judicial efectiva no se extiende a la ejecución, sino muy al contrario, porque no existía tal desprotección, ya que el Ministerio Fiscal está obligado a proteger legalmente a la víctima también en esta fase, con base en

${ }^{18}$ El Voto particular al "Informe al anteproyecto de ley orgánica del estatuto de las víctimas del delito" (Consejo General del Poder Judicial, 2014, pp. 9-10), recoge un resumen de esta jurisprudencia. 
el art. 3.10 del Estatuto Orgánico del Ministerio Fiscal de 1981, en el art. 541.1 LOPJ (que se refiere a las víctimas como ciudadanos), y en los arts. 105, 108, 110 y, sobre todo, el art. 773.1, I LECRIM.

El derecho de participación de la víctima en la ejecución de la pena de alguna manera nos tenía que llegar, porque ha sido una de las luchas más importantes en los Estados Unidos de los movimientos a favor de las víctimas, y hasta que no se ha logrado no se ha cejado en su empeño (Gómez, 2014, pp. 103 y ss.). Pero no ha pasado en la línea que estamos exponiendo a los países europeos más importantes, como Alemania o Italia (Gómez, 2014, pp. 145 y ss. y 172 y ss.), ni es norma europea todavía, como hemos dicho. Llega ahora a España, único país de los estudiados en donde la ejecución de la pena forma parte del contenido de la función jurisdiccional (art. 117.3 CE), por lo tanto, en España, la ejecución de la pena es competencia de un juez.

Lo que se pretende con esta norma es que la víctima sea oída mediante la concesión de un derecho al recurso específico antes de que, en la ejecución de la pena impuesta al autor del delito que le causó los daños y perjuicios, se dicten resoluciones firmes que puedan afectar a sus derechos al favorecer al condenado o incluso ponerlo en libertad antes de tiempo o cuando proceda sin contraprestación alguna, lo que puede contribuir a su victimización o incluso significar un riesgo serio para su seguridad personal.

Una puesta en libertad antes de tiempo del condenado no ajustada a la ley, sin haber sido la víctima completamente reparada en los daños y perjuicios sufridos, podría afectarle también negativamente si no se prevé expresamente esta cuestión. Supone, por lo tanto, un cambio radical respecto a la Disposición Adicional $5^{\text {a }}$ LOPJ, modificada en 2003, que únicamente permite recurrir resoluciones en ejecución al condenado y al Ministerio Fiscal.

La base de partida es doble: en primer lugar, que la víctima pida expresamente ser notificada de las resoluciones señaladas en el art. 13.1; y, en segundo lugar, que la víctima anuncie el recurso al Secretario Judicial antes de interponerlo, en los términos del art. 13.1, c)-II, no siendo necesario Abogado para ello (art. 13.1, c)-III).

Las resoluciones concretas son, atendido el art. 13.1, a), las siguientes ${ }^{19}$ :

${ }^{19}$ El Informe al Anteproyecto de Ley Orgánica del Estatuto de las Víctimas del Delito (Consejo General del Poder Judicial, 2014, p. 37), pidió que se 
En primer lugar, el auto del JVP que clasifica al penado en tercer grado, en los siguientes delitos: homicidio, aborto del artículo 144, lesiones, contra la libertad, tortura y contra la integridad moral, contra la libertad e indemnidad sexual, robo cometido con violencia o intimidación, terrorismo y trata de seres humanos. En segundo lugar, el auto del JVP acordando que los beneficios penitenciarios, los permisos de salida, la clasificación en tercer grado y el cómputo de tiempo para la libertad condicional se refieran al límite de cumplimiento de condena, con los condicionantes expuestos en esta norma. Y. en tercer lugar, el auto del JVP por el que se conceda al penado la libertad condicional, en los casos fijados por esta norma.

Obsérvese que se trata de resoluciones únicamente del Juez de Vigilancia Penitenciaria. Aunque en la ejecución española intervienen otros jueces que deciden, básicamente el tribunal sentenciador, esta norma no les es aplicable. Quizás por ello no se prevea el recurso contra la resolución de suspensión o de sustitución de las penas privativas de libertad (arts. 80, 81, 88 y $89 \mathrm{CP}$ ), porque es competencia del juez sentenciador. Pese a lo dicho, es importante advertir que el "Informe al anteproyecto de ley orgánica del estatuto de la víctima del delito" (Consejo Fiscal de la Fiscalía General del Estado, 2013, p. 15) y el "Dictamen sobre el anteproyecto de ley orgánica del estatuto de la víctima del delito" (Consejo de Estado, 2014, p. 20), no comparten esta exclusión.

No se ha incluido la propuesta de la FGE de que también se notificaran los cambios de segundo a tercer grado del penado, previo a su libertad condicional (Consejo Fiscal de la Fiscalía General del Estado, 2013, p. 16), dado el interés de la víctima de que no contribuya ello a adelantar la libertad condicional, que se presenta sin solución de continuidad.

La limitación a determinados delitos en el caso del auto del JVP que clasifica al penado en tercer grado no se explica fácilmente, pues aunque es claro que se trata siempre de delitos graves y que en ellos la víctima seguramente haya sufrido especialmente, el numerus clausus excluye en todo caso otros supuestos en que podrían darse las mismas explicaciones. La no inclusión específicamente de los delitos en materia de violencia de género es muy llamativa, salvo que se

ampliara la participación de la víctima en la ejecución pudiendo recurrir el auto suspensivo o sustitutivo de la pena privativa de libertad y cuando se decida la indemnización que le afecte. 
considere que están incluidos en los de homicidio, lesiones o contra la libertad sexual. Pero pensamos también en delitos de tráfico en los que el conductor causante del homicidio iba bebido o drogado, o en delitos de fraude bancario masivo, ejemplos ambos tenidos en España recientemente con enorme repercusión social, y me resisto a creer que no estemos ante supuestos semejantes para la víctima supérstite o para los ciudadanos que han perdido todos sus ahorros.

Nos preguntamos, entonces, a la vista de estas objeciones, por qué el listado de delitos del art. 13.1, a) no coincide con el del art. 23.2 , b). Sería todo mucho más fácil, dado que la gravedad del hecho y los perjuicios causados a la víctima se medirían por los mismos patrones. Tampoco es correcta la técnica de no referirse específicamente al delito regulado en un artículo concreto del Código Penal, porque la referencia a denominaciones de títulos legales de capítulos o a bienes protegidos en general puede plantear muchas dudas interpretativas.

Complementariamente, la víctima puede pedir en su recurso las medidas de protección necesarias para garantizar su seguridad si se ha decretado la libertad condicional del condenado, si éste lo ha sido por delito del que pueda inferirse ese peligro (art. 13.2, a). También puede proporcionar información al juez en su recurso para que tome la decisión más acertada a la hora de resolver en sede penitenciaria, las cuestiones a que se refiere el precepto. Esto recuerda claramente a las Victim Impact Statements norteamericanas, sólo que no se realizan en una vista oral, porque no está prevista, sino en un recurso escrito, y no influyen en la cuantía de la pena, porque ésta ya ha sido fijada en la sentencia, sino que pretenden tener incidencia en materia de beneficios penitenciarios (Gómez, 2014, pp. 103 y ss.).

El recurso puede ser o reforma, o apelación, o ambos a la vez, o incluso casación, dependiendo de las disposiciones de la LECRIM y de la Ley General Penitenciaria, y se tramita conforme a las mismas sin especialidad alguna, salvo el plazo (quizás demasiado amplio, por las razones antes indicadas, pues es de 15 días, art. 13.1, c) II PLEVict, lo que es innecesario si la víctima ha sido parte, y en todo caso, habría que homogeneizarlo con el plazo de 20 días del art. 636 LECRIM).

La ley no exige que la víctima haya sido parte en el proceso penal, lo que ha sido criticado ante la trascendencia del derecho que aquí 
se le está otorgando específicamente (Consejo General del Poder Judicial, 2014 p. 36 y Consejo de Estado, 2014, p. 21), pues aunque no esté prohibido por la legislación actual, lo cierto es que en la práctica la víctima nunca interviene en la ejecución de las penas, dado que no se entera de su desarrollo porque no tiene ninguna posibilidad de enterarse. El problema que plantea este derecho de la víctima es que por un sector jurídico importante se entiende que se podría conseguir un efecto no deseado, y es la utilización del recurso por parte de la víctima para continuar, o incluso aumentar, en todo caso para seguir extendiendo su venganza personal contra quien le ha causado el daño.

Esta objeción, sensata y fundada, se obvia de dos formas: primera, la víctima no puede condicionar en ninguna forma la decisión penitenciaria que se adopte, por lo tanto, el juez es siempre quien tiene la última palabra; $y$, segunda, la rehabilitación social del condenado es independiente de la opinión de la víctima y además tiene protección constitucional (art. 25.2 CE) frente a todos, incluida la propia víctima. En mi opinión, si en la práctica se garantiza la aplicabilidad de estos razonamientos, las venganzas no tienen cabida jurídica alguna, aunque se deseen por la víctima.

También se objeta que, puesto que la ejecución de la pena es de competencia pública, por un juez como acabamos de ver, la intervención de la víctima privatiza en cierto sentido esta fase final del proceso penal porque se hacen valer sus intereses particulares, lo que puede poner en peligro los principios de rehabilitación y reinserción social del condenado, ya que la intervención de la víctima podría ser decisiva para retrasar esa vuelta a la normalidad de la persona que ya ha pagado su culpa. Se objeta, en otras palabras, que la víctima pueda interferir el monopolio estatal del derecho de penar ${ }^{20}$.

Es fácil contestar a esta objeción, dado que no creemos que vuelva la privatización de la Justicia sólo por este tema. Creemos que la respuesta debe ser igual que en la objeción anterior y basarla en la competencia del juez para decidir, quien no puede dejarse influir por estas cuestiones. Si se aduce por la víctima riesgo para su

${ }^{20}$ Véase, el "Dictamen sobre el anteproyecto de ley orgánica del estatuto de la víctima del delito" (Consejo de Estado, 2014, pp. 19- 20). El Consejo de Estado comete un grave error al considerar que la ejecución de la pena "no forma parte ya del proceso penal propiamente dicho", ignorando el art. 117.3 CE, por eso debe leerse su opinión al respecto con mucha prevención en este punto. 
seguridad, debe probarse para que el juez deniegue el beneficio, y ello no es privatizar la ejecución de la pena.

Por último, sorprende, y mucho, que tratándose de un recurso la ley excluya la necesidad de complementar su postulación. Al menos el abogado debería ser de obligada exigencia, porque lo es para todas las partes personadas atendido el art. 221 LECRIM. Una vez más, el noble deseo de facilitar a una persona el acceso a la Justicia lo es a costa de posibilitar que lo haga mal, por ignorar cómo hacerlo, dando un trabajo adicional a los jueces al tener que suplir sus seguras deficiencias, que no ayuda en nada a una sana práctica de esta ley. Justificar por qué está en peligro su seguridad como víctima puede ser bastante complicado. El abogado ayuda decisivamente a que ni siquiera llegue a los tribunales esa petición si no consigue justificarse en el estudio previo, y ayuda a que se estime el recurso si está justificada pero es difícil de articular, lo que es el caso casi siempre. La misma preocupación se advierte en el "Informe al anteproyecto de ley orgánica del estatuto de la víctima del delito" (Consejo Fiscal de la Fiscalía General del Estado, 2013, p. 17) y el "Dictamen sobre el anteproyecto de ley orgánica del estatuto de la víctima del delito" (Consejo de Estado, 2014, p. 21).

Derecho a presentar denuncias en España siendo extranjero por delito cometido en el extranjero.

Finalmente, el art. 17 PLEVict -que traspone el art. 17 de la Directiva 2012 / 29 / UE- se dedica a las víctimas de delitos cometidos en otros estados miembros de la Unión Europea. No requiere de mayor comentario. Se trata de facilitar a esas víctimas que el delito sea perseguible en España, siguiendo a la Directiva 2012/29/UE, y si finalmente no puede ser perseguido en España, se remite al Estado en cuyo territorio se ha cometido el delito para que actúe.

\section{Sea o no sea parte. Derecho de protección.}

El PLEVict regula cuatro derechos de las víctimas, cuya característica común es que afectan su derecho a ser protegida, y se aplican tanto si la víctima decide no ser parte en el proceso penal, como si decide serlo. La preocupación máxima del PLEVict es establecer un derecho general de protección de la víctima, tanto si es parte en el proceso penal, como si va a serlo y todavía no lo es, como si nunca ha pensado en personarse, por lo tanto, válido sea o no sea parte, como antes hemos dicho. 
La exposición de motivos realiza, en su apartado VII, unas reflexiones generales al respecto. Este derecho general de protección se manifiesta en cuatro modalidades: primero, el derecho a la protección física (art. 19); segundo, el derecho a que se evite el contacto entre víctima e infractor (art. 20); tercero, el derecho a protecciones específicas durante la fase de investigación del crimen (art. 21); y, cuarto, el derecho a la protección de la intimidad (art. 22).

\section{Derecho a la protección física.}

El primer derecho de las víctimas es el derecho a la protección, que es, obviamente, el que afecta con carácter general a la integridad física y psíquica, pero no solamente. Se regula en el art. 19 PLEVict, el cual traspone el art. 18 de la Directiva 2012/29/ UE. Se trata de una norma destinada a la Policía, a la Fiscalía y al Poder Judicial, pues establece con carácter general la obligación de estas autoridades de proteger: (a) la vida de la víctima y de sus familiares; (b) la integridad física y psíquica de la víctima; (c) su libertad; (d) su seguridad; (e) su libertad e indemnidad sexuales; (f) su intimidad; y (g) su dignidad.

Esta protección debe dispensarse especialmente cuando se reciba declaración a la víctima o a sus familiares, o cuando deba testificar en juicio. Su fin es obvio, a pesar de ello la ley nos dice que se pretende evitar el riesgo de su victimización secundaria o reiterada.

\section{Derecho a que se evite el contacto entre víctima e infractor.}

El segundo derecho reconocido por el PLEVict, es muy importante atendida la realidad práctica, pues se trata de evitar el contacto entre víctima e infractor. Se regula en el art. 20, que traspone el art. 19 de la Directiva 2012/29/UE. Está indicado en ciertos casos, sobre todo, cuando la víctima lo es de un delito provocado por la criminalidad organizada, especialmente por terroristas o mafiosos, o cuando la víctima lo es de un delito de naturaleza sexual, o cuando es víctima de la violencia de género, casos todos ellos en los que el contacto con su agresor puede significar para la víctima un peligro real de su vida e integridad física. Hay que relacionar esta disposición por tanto con la medida de protección del art. 25.1 a) PLEVict.

La norma se refiere a evitar el contacto en dependencias, pero debería ser mucho más precisa, afectando a todos los locales y lugares donde tengan lugar actos orales en los que en situaciones normales 
autor del delito y víctima coincidirían, y también a la preparación de los mismos y después de su finalización. Por tanto, debería darse en todos aquellos casos en los que una orden de alejamiento no pueda aplicarse y el peligro de contacto sea real.

Claro que, en el caso de que no existan tales dependencias aún, ¿qué hacemos? Pues cumplir el espíritu de la ley como sea, ubicando al agresor y a su víctima en despachos o salas diferentes, porque en mi opinión, si ello no se respeta, al no preverse sanción alguna para el responsable de que exista la sala, que no sabemos quién es, la norma carece de relevancia alguna, y la victimización secundaria para la víctima sería segura.

Derecho a protecciones específicas durante la fase de investigación del crimen.

El PLEVict establece unas protecciones específicas en el art. 21, bajo el título general de 'Protección de la víctima durante la investigación penal' que también traspone el art. 19 de la Directiva 2012 / 29/UE. Las protecciones que dispensa esta norma son lógicas. Nos llama la atención que puedan estar acompañadas, además de su abogado, por una persona de su elección (art. 21, c), medida muy positiva porque ésa es la persona en la que más se va a apoyar toda víctima que tenga que pasar por los diferentes trances judiciales, ya que se tratará de la persona con la que más confianza tenga. Lo que sorprende es que ese derecho pueda ser limitado 'para garantizar el correcto desarrollo de la misma'. Al no darse causas de exclusión en la ley, no sabemos muy bien qué quiere decir la frase, ni imaginamos cómo puede interferir negativamente el acompañante, ya que ello perjudicaría sin duda a la víctima a la que acompaña. También destacamos el deseo legislativo de que la víctima declare el menor número de veces, cuanto antes, $\mathrm{y}$, en definitiva, que como mucho con una exploración médica debe bastar.

\section{Derecho a la protección de la intimidad.}

Finalmente, se protege con carácter especial el derecho a la protección de la intimidad de la víctima en el art. 22 PLEVict; como los dos anteriores, traspone el art. 19 de la Directiva 2012/29/UE. La protección de la intimidad por las autoridades descritas en el precepto es específica para la víctima y sus familiares, por ello se centra básicamente en que su identidad no sea conocida. Si es una víctima normal la vulneración de la intimidad, siempre grave, puede 
ser sin embargo menos perjudicial, pero si se trata de un menor de edad o de una persona discapacitada necesitada de especial protección, la vulneración de su intimidad puede ser letal, de ahí la especial referencia en el texto legal a esta cuestión.

Parece adecuado, como ha propuesto el Consejo Fiscal de la Fiscalía General del Estado (2013, p. 21), que no se difunda, ni a las demás partes ni a nadie, únicamente al órgano jurisdiccional, su domicilio y demás datos de interés que puedan hacer inútil esta norma, como su correo electrónico, red social, etc. Téngase en cuenta que hay un desarrollo específico de la protección de la intimidad en el propio PLEVict al reformar en su Disposición Final $2^{\mathrm{a}}$ los arts. 681, 682 y 707 LECRIM, que comentamos infra.

\section{Medidas de protección específicas de las víctimas vulnerables.}

Las medidas de protección de las víctimas se fijan en los arts. 25 y 26 PLEVict. La ley distingue entre las medidas de protección aplicables a cualquier víctima y las medidas aplicables sólo a menores de edad y discapacitados, en su calidad de víctimas esencialmente vulnerables con evaluación positiva favorable a una protección especial.

Las primeras, esto es, las medidas de protección aplicables a cualquier víctima se regulan en el art. 25 PLEVict, cuya inclusión supone la trasposición del art. 23 de la Directiva 2012/29/UE, teniendo en cuenta la compatibilidad expresa con otras medidas específicamente aprobadas para víctimas concretas, como las medidas de protección de las víctimas de la violencia de género previstas en los arts. 61 y ss. (Ley Ordinaria 1 de 2004).

Las medidas son por sí mismas claras. La ley distingue entre las fases de investigación y la de enjuiciamiento: para la de investigación, la toma de declaraciones debe realizarse en lugares especialmente diseñados, por la misma persona, que puede no ser el juez o el fiscal, sino un profesional con formación especial, y en determinados casos (delitos de violencia de género y libertad o indemnidad sexual) del mismo sexo.

Para la de enjuiciamiento, y también en resumen, medidas que eviten el contacto visual entre la víctima y el agresor, para garantizar que la víctima pueda ser oída sin estar presente en la sala de vistas, para evitar que se formulen preguntas relativas a la vida privada de la víctima salvo que el juez o el tribunal dispongan lo contrario, y celebración de la vista oral sin presencia de público, aunque sí 
pueden estar presentes personas que acrediten un especial interés en la causa.

Las medidas relativas a evitar preguntas sobre su vida privada y ausencia de público en la vista también podrán ser adoptadas durante la fase de investigación (art. 25.2, d)-II PLEVict), en tanto sean aplicables, se supone.

No sabemos quiénes son las personas que pueden acreditar un especial interés en la causa para que no se les aplique la exclusión de la publicidad del juicio oral o de la vista. Podemos pensar en aquella persona de su elección que la puede acompañar y que no es su abogado (art. 4, c) PLEVict), pero dada la amplitud de la expresión, también podría ser la Administración, un profesional o un particular, relacionado con la víctima o no. Demasiado genérico, vale la pena precisar, pensando, claro en excluir a aquéllos que al asistir pueden perjudicar a la víctima. El "Dictamen sobre el anteproyecto de ley orgánica del estatuto de la víctima del delito" llama la atención sobre este problema (Consejo de Estado, 2014, p. 22).

Si la víctima comparece como testigo, puede adoptarse, además, alguna de las medidas previstas en el art. 2 de la Ley Ordinaria 19 de 1994 (art. 25.3), a saber, las tres siguientes: Que no consten en las diligencias que se practiquen, su nombre, apellidos, domicilio, lugar de trabajo y profesión, ni cualquier otro dato que pudiera servir para la identificación de los mismos, pudiéndose utilizar para esta un número o cualquier otra clave. Así mismo, que comparezcan para la práctica de cualquier diligencia utilizando cualquier procedimiento que imposibilite su identificación visual normal; $y$, que se fije como domicilio, a efectos de citaciones y notificaciones, la sede del órgano judicial interviniente, el cual las hará llegar reservadamente a su destinatario.

Debe entenderse, finalmente, que el concepto de víctima que se emplea aquí es tanto el directo como el indirecto del art. 2 PLEVict, para que incluya a los familiares en los casos en los que las disposiciones del art. 25 les sean de aplicación. No habría estado de más, como ha propuesto el Consejo de Estado (2014, p. 22), que se dijera expresamente. Ello habría respetado mejor la Directiva 2012/29/UE.

Las segundas, o sea las medidas de protección para menores y personas con discapacidad necesitadas de especial protección que 
sean víctimas de un delito, a efectos de garantizar su máxima protección, sobre todo frente a los peligros que entraña su declaración, se regulan en el art. 26, que traspone el art. 24 de la Directiva 2012 / 29 / UE, y que debe relacionarse con los arts. 433 y 448, III LECRIM, también reformados por el PLEVict.

En resumen, las declaraciones de estas víctimas especialmente vulnerables serán grabadas (pudiendo ser reproducidas en el juicio) y tomadas por expertos (art. 26.1). Se intenta evitar que declaren en el juicio oral, reproduciéndose en él la prueba preconstituida, lo que por un lado evita una segura victimización secundaria, pero, por otro, entraña ciertamente si es regla general, un riesgo de vulneración de los derechos constitucionales del acusado al negarse así la debida confrontación que produce la inmediación. Con ciertos límites, se admiten jurisprudencialmente estas restricciones constitucionales a favor de la víctima menor de edad (TJUE, Pupino vs Italia, 2005 y TS Sentencia 290 de 2012, RJ 2012 \5759, entre otras).

Además, se le nombrará por el juez de instrucción -o por el juez de menores, aunque no lo diga la ley (Consejo General del Poder Judicial, 2014, p. 45.)- un defensor judicial a instancias del Ministerio Público, si la víctima tiene conflicto con sus representantes legales, o con uno de ellos no estando en condiciones el otro de asumir la representación legal, y si no está acompañada o se encuentra separada de quienes ejerzan la patria potestad o cargo tutelar (art. 26.2).

Particularmente, en cuanto a los menores de edad víctimas de delito contra la libertad o indemnidad sexual, se les protegerá mediante las mismas medidas que a cualquier víctima en la fase de investigación previstas en el art. 25.1, con excepción de toma de declaración por persona del mismo sexo (art. 23.3 PLEVict, apartado que no debería figurar en este precepto, sino en el art. 26). Finalmente, todas las medidas de protección acordadas con base en los arts. 25 y 26 son renunciables por la víctima (art. 24.2, II PLEVict, precepto que igualmente estaría mejor ubicado o en el art. 25 o en el art. 26).

Por otra parte, la especial protección es un criterio jurídico que debe ser valorado específicamente. No es un criterio general aplicable únicamente por ser una víctima incardinada en un grupo concreto de seres desfavorecidos. Por lo tanto, cada víctima tiene que ser sometida a un análisis personal, familiar, laboral y de entorno social, antes de que se le pueda aplicar una medida de 
protección específica de las recogidas en los arts. 25 y 26, acabadas de analizar.

Ese análisis se regula mediante reglas específicas, consistentes básicamente en la necesidad de que la víctima sea sometida previamente a un procedimiento de evaluación, cuyo resultado determinará sus necesidades especiales de protección o las rechazará. Se regula en los arts. 23 y 24 .

El procedimiento de evaluación: se establece en el art. 23, que traspone el art. 22 de la Directiva 2012/29 / UE, es individual y su fin es determinar las necesidades especiales de protección de determinadas víctimas. Es un precepto importante porque nos da una idea, incompleta ${ }^{21}$ pero aproximada, de qué víctimas son para el legislador especialmente vulnerables, en función de la consideración de sus características personales, la naturaleza del delito y la gravedad de los perjuicios causados, considerando particularmente siete delitos muy graves, y las circunstancias del delito, especialmente si es violento.

La competencia y procedimiento de evaluación se regulan en el art. 24, el cual constituye una trasposición de varios preceptos (arts. 1.2, 8.1 y 3, 22.6 y 7) de la Directiva 2012/2/UE, que requerirá de desarrollo reglamentario. La medida la valora por regla general el juez competente para la instrucción durante la fase de investigación, y el juez o tribunal competente para el juicio oral, y también por el fiscal en los procesos en que sea competente para instruir, decretándose mediante auto, siempre actualizable.

\section{Derechos procesales no penales}

El PLEVict regula un derecho procesal civil, la devolución de bienes incautados en el proceso penal a la víctima que sea su propietaria, tanto si ha sido parte como si no (art. 18), que traspone

${ }^{21} \mathrm{El}$ "Informe al anteproyecto de ley orgánica del estatuto de la víctima del delito" (Consejo Fiscal de la Fiscalía General del Estado, 2013, p. 21); y el "Informe al Anteproyecto de ley orgánica del estatuto de las víctimas del delito" (Consejo General del Poder Judicial, 2014, pp. 42-43), pidieron, sin éxito alguno, que se incluyeran los delitos de homicidios, lesiones graves y los de detenciones ilegales y secuestros, porque podrían ser incluidos en las desapariciones forzosas. El "Dictamen sobre el anteproyecto de ley orgánica del estatuto de la víctima del delito" (Consejo de Estado, 2014, p. $22)$, les apoya. 
el art. 15 de la Directiva 2012/29/UE. Podría haber regulado más, por ejemplo, establecer un baremo específico de daños teniendo en cuenta la vulnerabilidad de la víctima en función de la agresión, a efectos de fijación de la indemnización económica concreta e igual para todos, pero no lo ha hecho. Sorprendentemente, en España el valor de las víctimas es desigual: las víctimas de la violencia de género perciben indemnizaciones diez veces menor a la de las víctimas del terrorismo (El País, 2014, p. 18).

Si es parte en el proceso penal es un derecho superfluo, porque ya está regulado en el art. 2.4 ${ }^{\mathrm{a}}$, C) del Real Decreto 2783 de 1976, sobre conservación y destino de piezas de convicción, con base en los arts. 334, 338 y 770.3 LECRIM, aunque ahora es mucho más claro y tiene rango de ley. Por lo tanto, es más bien aplicable a cuando la víctima no es parte o todavía no lo es. Obviamente, la víctima tiene que demostrar que es la propietaria del bien o bienes para obtener su restitución sin demora. Puede imponérsele una obligación de conservación de los mismos, para que estén disponibles si el juez o el tribunal los reclaman.

Pero lo importante es que ese derecho puede ser denegado en uno de estos dos casos: primero, si el bien es imprescindible que permanezca a disposición del juzgado o tribunal a efectos de un correcto desarrollo del proceso penal (art. 18, II); o, segundo, si la conservación del bien en el proceso es necesario por investigarse técnicamente un accidente, se supone que en un proceso penal por delito contra la seguridad vial, aunque la ley no lo dice (art. 18, III). Hay que estar, finalmente, a lo dispuesto en los arts. 284 y 334 LECRIM, modificados por la Disposición Final 2a del PLEVict. El art. 334 regula además el recurso que debe caber al prever el art. 18 una denegación del derecho. Quizás por ello debería haberse llevado este art. 18 a la LECRIM y no estar ubicado aquí.

\section{Referencias}

Armengot, A. (2014). La incorporación de la mediación en el proceso penal español. La Ley penal, (106), 7.

Barona, S. (1999). Solución extrajurisdiccional de conflictos. Valencia: Tirant lo Blanch.

Barona, S. (2009). La mediación penal para adultos. Una realidad en los ordenamientos jurídicos. Valencia: Tirant lo Blanch. 
Barona, S. (2010). El presente y el futuro de la mediación entre autor y víctima en España. En J. Tamarit (Ed.), Victimas olvidadas (pp. 229-254). Valencia: Tirant lo Blanch.

Cancio, M. (1998). Conducta de la víctima e imputación objetiva en Derecho Penal. Barcelona: Bosch.

Castillejo, R. y Benavente, M. A. (2011). Violencia de género, justicia restaurativa y mediación. Madrid: La Ley.

Cervelló, V. (2013). Principios y garantías de la mediación penal desde el enfoque resocializador y victimológico. Revista Penal, (31), 22-51.

Consejo de Europa. Comité de Ministros de los Estados miembros sobre asistencia a víctimas del delito Recomendación 8 de 2006. Recuperado de http:/ / es.slideshare.net/mariadaza3958/ recomendacin-2006-8-ctmtros-consejo-de-europa-traduccin.

De Vicente, J. (1997). La consideración de la víctima a través de la reparación del daño en el Derecho penal español: Posibilidades actuales y perspectivas de futuro. En J. M. Silva (Ed.), Política Criminal y nuevo Derecho Penal (pp. 173-206). Barcelona: Bosch.

Estrasburgo. Directiva 64 de 2010. Relativa al derecho a interpretación y a traducción en los procesos penales. Diario oficial DO I. 280/1. Parlamento Europeo y Consejo de las Comunidades Europeas, octubre de 2010. Recuperado de http:/ / www.eulita.eu/sites/default/files/directive_es.pdf

Estrasburgo. Directiva 29 de 2012. Por la que se establecen normas mínimas sobre los derechos, el apoyo y la protección de las víctimas de delitos, y por la que se sustituye la Decisión marco 2001/220/AI del Consejo. Diario oficial DOI. 315/57. Parlamento Europeo y Consejo de las Comunidades Europeas, octubre de 2012. Recuperado de https:// www.boe.es/ doue/2012/315/L00057-00073.pdf.

Estrasburgo. Directiva 13 de 2012. Relativa al derecho a la información en los procesos penales, Diario oficial DO I. 142/1. Parlamento Europeo y Consejo de las Comunidades Europeas, mayo de 2012. Recuperado de https: / / www.boe.es / doue/2012/142/L00001-00010.pdf

Fairén, V. (1992). Derecho Presente y Futuro II Tendencias actuales del Derecho Procesal Penal. En V. Fairén (Ed.), Estudios de Derecho Procesal Civil, Penal y Constitucional. III: La reforma procesal penal 1988-1992. Madrid: Edersa.

Fernández, M. D. (2004). La intervención de la víctima en el proceso penal. Valencia: Tirant lo Blanch.

Ferreiro, X. (2005). La víctima en el proceso penal. Madrid: La Ley. 
Galain, P. (2010). La reparación del daño a la víctima del delito. Valencia: Tirant lo Blanch.

Garciandía, P. M. (2012). La regulación de la mediación penal en España: Opciones legislativas y contenidos mínimos. En J. L. Gómez, S. Barona \& M. P. Calderón (Eds.), El Derecho Procesal español del siglo XX a golpe de tango (pp. 1005-1032). Valencia: Tirant lo Blanch.

Gómez, J. L. (1996). El nuevo régimen del beneficio de la asistencia jurídica gratuita. La Ley, (2), 1579-1587.

Gómez, J. L. (2014). Estatuto Jurídido de la Víctima del Delito. Pamplona: Thomson Reuters Aranzandi.

Gómez, J. L. (2015). Notas sobre la justicia procesal (alternativa, negociada, transaccional, restaurativa o reparadora). Un nuevo subsistema de Justicia para aliviar al sistema de Justicia Judicial. En R. Castillejo, M. J. Sande, \& T. C. Torrado (Eds.), Justicia restaurativa y violencia de género. Más allá de la ley orgánica 1/2004 (pp. 169-200). Santiago: Universidad Santiago de Compostela.

Quintero, G. (2011). Sobre la mediación y la conciliación en el sistema penal español: situación y perspectivas de futuro. En R. Castillejo Manzanares, \& M. Á. Catalina Benavente (Eds.), Violencia de género, Justicia restaurativa y mediación. Madrid: La Ley.

Reino de España. Proyecto de ley ordinaria 115-1 de 2014. Boletín Oficial de las Cortes Generales. Congreso de los Diputados, X Legislatura, Serie A, septiembre de 2014.

Reino de España. Real Decreto 2783 de 1976. Sobre conservación y destino de piezas de convicción. BOE No. 294. Ministerior de la Presidencia, octubre de 1976.

Reino de España. Ley Ordinaria 19 de 1994. De Protección de Testigos y Peritos en Causas Criminales. BOE No. 307. Congreso de los Diputados, diciembre de 1994.

Reino de España. Ley 35 de 1995. De ayudas y asistencia a las víctimas de delitos violentos y contra la libertad sexual. BOE No. 296. Ministerio de la Presidencia, diciembre de 1995.

Reino de España. Ley 1 de 1996. De asistencia jurídica gratuita. BOE No. 11. Ministerio de la Presidencia, enero de 1996.

Reino de España. Ley Orgánica 5 de 2000. Reguladora de la responsabilidad penal de menores. BOE No. 11. Ministerio de la Presidencia, enero de 2000.

Reino de España. Real Decreto 658 de 2001. Estatuto General de la Abogacía Española. BOE No. 164. Ministerio de la Presidencia, junio de 2001. 
Reino de España. Ley Orgánica 1 de 2004, de 28 de diciembre, de Medidas de Protección Integral contra la Violencia de Género. BOE No. 313. Ministerio de la Presidencia, diciembre de 2014.

Reino de España. Ley 29 de 2011, de Reconocimiento y Protección Integral a las Víctimas del Terrorismo. BOE No. 229. Ministerio de la Presidencia, Septiembre de 2011.

Reino de España. Ley 5 de 2012, de Mediación en asuntos civiles y mercantiles. BOE No. 162. Ministerio de la Presidencia, julio de 2012.

Reino de España. Consejo Fiscal Fiscalía General del Estado (2013). Informe al Anteproyecto de Ley Orgánica del Estatuto de la Víctima del Delito.

Reino de España. Consejo de Estado. (2014) Dictamen sobre el Anteproyecto de Ley Orgánica del Estatuto de la Víctima del Delito (Documento CE-D 2014360). Ministerio de la Presidencia. Recuperado de http:/ / www.boe.es / buscar/ doc.php?id=CE-D-2014-360

Reino de España. Consejo General del Poder Judicial (2014). Informe al Anteproyecto de Ley Orgánica del Estatuto de las Víctimas del Delito. Recuperado de http://www.poderjudicial.es/cgpj/es/Poder-Judicial/ConsejoGeneral-del-Poder-Judicial/ Actividad-del-CGPJ/Informes/Informe-alAnteproyecto-de-Ley-Organica-del-Estatuto-de-las-Victimas-del-delito

Reino de España. Sentencia 71 (1988, abril 19). Tribunal Constitucional de España.

Reino de España. Sentencia 12 (2011, febrero 2) (RJ $\backslash 2011 \backslash 324)$. Tribunal Supremo Español.

Reino de España. Sentencia 290 (2012) (RJ $\backslash 2012 \backslash 9869)$. Tribunal Supremo Español.

Reino de España. Sentencia 783 (2012, octubre 25) (RJ $\backslash 2012 \backslash 9869)$. Tribunal Supremo Español.

De Hoyos, M. (2014). Reflexiones sobre la Directiva 2012/29/UE, por la que se establecen normas mínimas sobre los derechos, el apoyo y la protección de las víctimas de delitos, y su transposición al ordenamiento español. Revista General de Derecho Procesal, (34),1 y ss.

Kamasinski vs. Austria. (1989, diciembre 19). Tribunal Europeo de Derechos Humanos.

Pupino vs. Italia. (2005, junio 16). Tribunal de Justicia de la Unión Europea.

Silva, J. (1993). La consideración del comportamiento de la víctima en la teoría jurídica del delito. Observaciones doctrinales y jurisprudenciales 
sobre la «victimo-dogmática» (pp. 11-52). En La Victimología. Madrid: Cuadernos de Derecho Judicial.

Tamarit, J. (1994). La reparación de la víctima en el Derecho Penal (estudio y crítica de las nuevas tendencias políticos-criminales). Barcelona: CEJIFE G. Catalunya y F. Jaume Callís.

Varona, G. (2000). Justicia criminal a través de procesos de mediación: una introducción (pp. 37-56). En Las víctimas en el proceso penal. Universidad del País Vasco.

Varona, G. (2011). La justicia restaurativa y la mediación penal. En I. Olaizola Nogales, \& P. Francés Lecumberri (Eds.), Jornadas de Justicia Restaurativa. Universidad Pública de Navarra. 